\title{
Pollution Characteristics of Heavy Elements in Nanchang, China Street Dust
}

\author{
Xiaoling Xu' ${ }^{1}$, Hua Zhang ${ }^{1,2 *}$, Xiaoying Xiong ${ }^{1}$, Huaming Zhang ${ }^{1}$, \\ Huan Zeng', Wenjing Yang1,2 \\ ${ }^{1}$ Key Laboratory of Education Ministry for Poyang Lake Wetland and Watershed Research, Geography \\ and Environmental College, Jiangxi Normal University, Nanchang, P.R. China \\ ${ }^{2}$ Jiangxi Provincial Key Laboratory of Poyang Lake Comprehensive Management and Resource Development, \\ Jiangxi Normal University, Nanchang, China
}

Received: 13 January 2019

Accepted: 12 February 2019

\begin{abstract}
Heavy elements are always the major pollutants in urban areas, and their pollution levels and spatial distributions vary among various land use types. In this study, we investigated the concentrations, pollution levels, spatial-temporal distributions, and health risks of 23 elements in street dusts $(<63 \mu \mathrm{m})$ along the urban expansion in metropolitan Nanchang. The average concentrations of $\mathrm{Cu}, \mathrm{Zn}, \mathrm{Cd}, \mathrm{Pb}, \mathrm{Sr}$, $\mathrm{Te}, \mathrm{Ba}, \mathrm{Sn}, \mathrm{Sb}$, and $\mathrm{Bi}$ were distinctly higher than their background values, and most of their enrichment factor (Ef) $>2$, indicating anthropogenic inputs as the major sources. The majority of elements in dust had high spatial heterogeneities and area characteristics. Seasonality had a minor effect on the variation of element concentrations, but had a significant effect on the modified degree of contamination index $\left(\mathrm{mC}_{\mathrm{d}}\right)$ of elements. The quantity of elements with characteristics of anthropogenic fingerprint $(\mathrm{Ef}>2)$ was identified as an indicator of urban expansion due to it being consistent with the distributions of population density and traffic flow. The enrichment of $\mathrm{Cd}$, $\mathrm{Sr}$, and $\mathrm{Sb}$ contributed $36.38-46.96 \%$ to the $\mathrm{mC}_{\mathrm{d}}$. The $\mathrm{mC}_{\mathrm{d}}$ values decreased significantly along urban expansion, which happened only in summer. Most elements in street dusts had multiple sources and were highly related to the traffic input due to their close correlation with the recognized anthropogenic-related elements such as $\mathrm{Cd}$ and $\mathrm{Pb}$. The $\mathrm{HI}$ values for all the elements were below the safe level, suggesting a non-carcinogenic risk to inhabitants. The exposure for As and $\mathrm{Cd}$ in dusts caused significant carcinogenic risk to inhabitants. High concentration, Ef value, and $\mathrm{HI}$ value of $\mathrm{Sb}$ possibly caused adverse health risks and requires more attention.
\end{abstract}

Keywords: street dust, heavy elements, urban expansion, seasonality, health risk 


\section{Introduction}

About $54.5 \%$ of the world's population settled in urban areas before 2016, based on the statistical estimation from the United Nations [1]. Meanwhile, city expansion and rapid urbanization are common phenomena around the world, especially in developing countries [2]. As a consequence, the results of a high percentage of human activity have placed great stress on the urban environment, which in turn threatens public health [3, 4]. Heavy elements regarded as priority pollutants are the immediate consequence of human activities such as traffic exhaust, industrial emissions, and municipal waste disposal [5-7]. The medium such as soil, air, water, and dust in many cities have been determined to contain high levels of heavy elements [4, 8-10].

Street dust mainly consists of solid mater and is an important medium in the urban ecological system $[4,11]$. Compared to soil, street dust is more sensitive and has been reported to have high levels of heavy elements [12], thus presenting a greater hazard to human health. Moreover, street dust mainly from atmospheric depositions is also easily re-suspended to dominate the atmospheric particulate matter (PM) [11]. It was calculated that street dust contributed $57 \%$ ambient levels to coarse particle fraction $(3.0-10 \mu \mathrm{m})$, and also accounted for $28 \%$ of the fine size fraction $(<3.0 \mu \mathrm{m})$ [13]. Elements adhering to these PMs are easily absorbed by human bodies through ingestion, inhalation and dermal contact, which cause hazards to health [7]. Therefore, it is necessary to study the heavy element enrichment in street dust from urban environments.

Indeed, increased literature about heavy elements in street dust has focused on concentrations, spatial variation, source identifications, bioavailability by fraction analysis, and pollution levels by some indices such as geo-accumulation index $\left(\mathrm{I}_{\text {geo }}\right)$, enrichment factor (Ef), potential risk index (RI), and health risk assessment via hazard index (HI) and carcinogenic risk (CR) [4, 12, 14-18]. Observed linkage between magnetic signature and heavy elements in street dust was also reported [11, 19]. Most of published works determined the concentrations of heavy element in dust with particle size $<75 \mu \mathrm{m}$ due to it enriched of more than $90 \%$ of the heavy elements and easily transported in suspension [20-21]. All previous studies seemingly provided enough information for understanding the behaviors of heavy element in dust from urban areas. However, some deficiencies need more attention: (i) most studies put the priority issue on the distribution of heavy elements in dust from different land-use settings (functional area) $[18,22]$, but have paid less attention to the effect of urban expansion on heavy elements in street dust from metropolitan areas; (ii) the spatial variation of element concentrations had been widely reported, while in contrast, studies about seasonal variation were quite limited $[4,11]$; (iii) most studies focused on quite a few elements, such as $\mathrm{Cr}, \mathrm{Ni}, \mathrm{Cu}, \mathrm{Zn}, \mathrm{As}, \mathrm{Cd}$, and $\mathrm{Pb}$, which were always identified as anthropogenic sources [2324]. Hence, to overcome the above gaps, the objectives of this study were to: (1) characterize the seasonal variations of the 23 elements (Ti, $\mathrm{Li}, \mathrm{Sc}, \mathrm{V}, \mathrm{Cr}, \mathrm{Co}, \mathrm{Ni}$, $\mathrm{Cu}, \mathrm{Zn}, \mathrm{Ga}, \mathrm{As}, \mathrm{Rb}, \mathrm{Sr}, \mathrm{Cd}, \mathrm{Sn}, \mathrm{Sb}, \mathrm{Te}, \mathrm{Cs}, \mathrm{Ba}, \mathrm{W}, \mathrm{Tl}$, $\mathrm{Pb}, \mathrm{Bi}$ ) in street dust from a metropolitan area along an urban expansion; (2) to modify the contamination degree index $\left(\mathrm{C}_{\mathrm{d}}\right)$ in order to evaluate the pollution level of heavy elements in street dust; and (3) assess the risks posed to human health (children and adults) through ingestion, inhalation, and dermal contact due to exposure to heavy elements in street dust.

\section{Materials and Methods}

\section{Study Area and Sampling Collection}

Nanchang $\left(28^{\circ} 09^{\prime} \sim 29^{\circ} 11^{\prime} \mathrm{N}, 115^{\circ} 27^{\prime} \sim 116^{\circ} 35^{\prime} \mathrm{E}\right)$, the capital of Jiangxi Province, is situated in the middle part of the Yangtze delta of China. Its area is 7432.17 $\mathrm{km}^{2}$ with a population of 5.10 million inhabitants. It is characteristic of subtropical humid monsoon with an average annual temperature of $17 \sim 18^{\circ} \mathrm{C}$ and average annual rainfall of $1600 \mathrm{~mm}$ [25]. Just like other cities in China, urbanization and industrialization of Nanchang in the past 3 decades has increased at a very high and extraordinary pace. These drastic changes inevitably affect the urban environment.

The typical transection extending from the center to the fringe on behalf of the urban expansion of Nanchang was chosen as the study area. Three areas were divided, based mainly on administrative boundary characteristics of distinctive ages. Xihu and Donghu districts, being mainly developed before the 1930s, were the core area of Nanchang. Qingshanhu District was formed before the 1980s as part of urban expansion. The Gaoxin District was established in 2003 and indicated the periurban area, which became part of metropolitan Nanchang. In view of the above-mentioned details regarding urban expansion, parts of Xihu and Donghu districts were chosen as the center area, part of Qingshanhu was named as the extension area, and part of Gaoxin was chosen as the fringe area in this study (Fig. 1). A total of 132 street dust samples (3 sub-samples for each sampling site) were collected from the center area $(\mathrm{N}=26)$, extension area $(\mathrm{N}=23)$, and fringe area $(\mathrm{N}=19)$ during summer $(\mathrm{n}=68)($ July 2015) and winter $(\mathrm{n}=68)$ (January 2016). The basic meteorological parameters (temperature, relative humidity, rainfall, wind speed, and wind direction) during sampling are presented in Table S1. In addition, the other parameters (population density and traffic flow) in each area were also provided in Table S2. The dust sampling was arranged after a successive five (at least) dry period. We used clean plastic brushes to sweep an area of about $1 \mathrm{~m}^{2}$ adjacent to the curb of the street to composite one sub-sample. A 200-300 g 


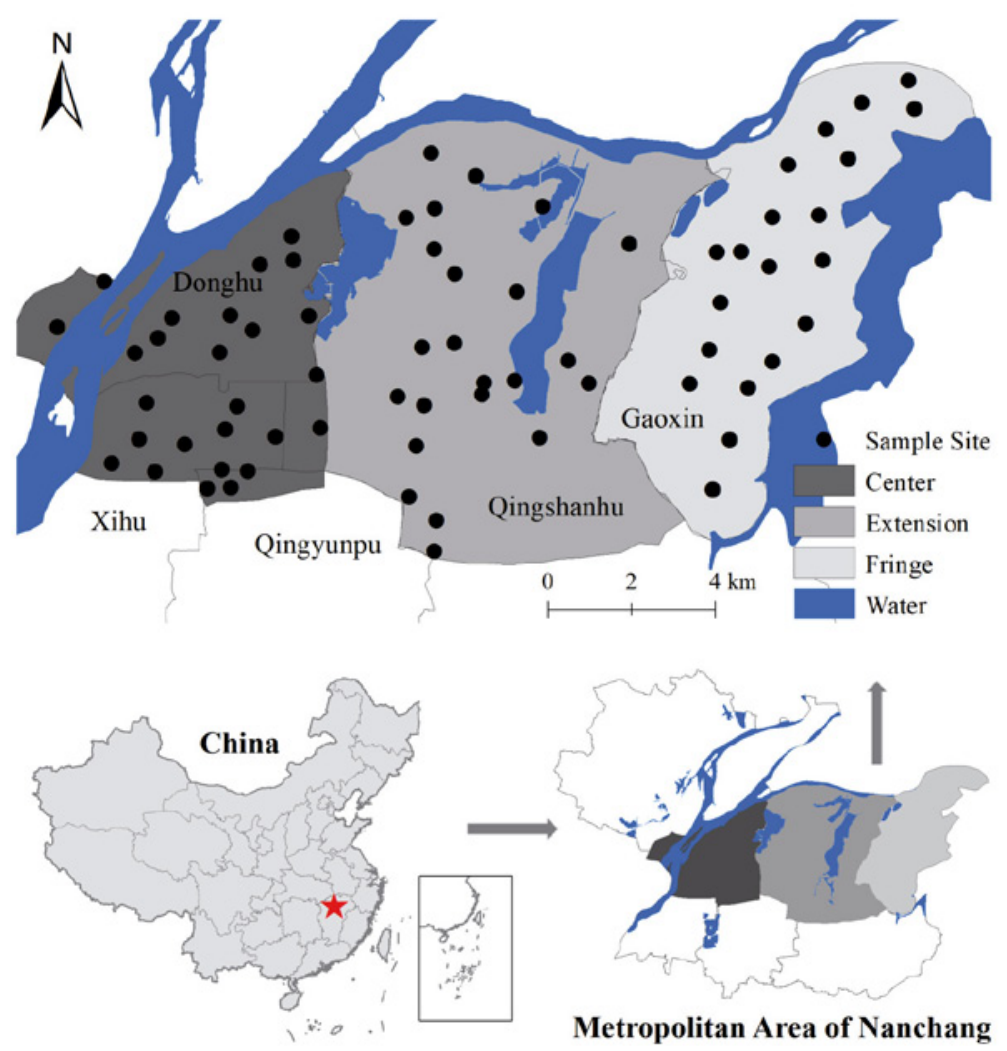

Fig. 1. Sampling site distributions in center, extension and fringe areas of Nanchang, China.

dust sample composed of 3 sub-samples was collected at each site and wrapped in aluminum foil and transferred to the laboratory as soon as possible. The samples were air-dried for 7-15 days and passed through a $2 \mathrm{~mm}$ nylon sieve to remove coarse materials such as stone, plastic, leaves, and hair. Then all samples were sieved through 220 mesh nylon sieve $(<63 \mu \mathrm{m})$ for analysis due to street dust with diameters $<63 \mu \mathrm{m}$ mainly arising from atmospheric deposition and easily being transported by resuspension [15].

\section{Chemical Analysis}

The method for extraction of heavy element concentrations in street dust samples with diameters $<63 \mu \mathrm{m}$ was established in our previous study [26]. In brief, total metal extraction was performed by $\mathrm{HNO}-\mathrm{HF}-\mathrm{HCl}$ mixture in a Teflon digestion bomb and diluted for analysis. The total concentrations of elements (Ti, Li, Sc, V, Cr, Co, Ni, Cu, Zn, Ga, As, Rb, Sr, Cd, $\mathrm{Sn}, \mathrm{Sb}, \mathrm{Te}, \mathrm{Cs}, \mathrm{Ba}, \mathrm{W}, \mathrm{Tl}, \mathrm{Pb}, \mathrm{Bi}$ ) were determined by inductively coupled plasma mass spectrometry (ICP-MS, Thermo X series II, USA).

The experiments were performed under strict quality control. All of the containers were soaked in $10 \% \mathrm{HNQ}_{3}$ before the experiments. All reagents used were of guaranteed grade. Standard reference materials (Geochemical Standard Soil GSS-5, GSS-9) were used for quality assurance and quality control. The recoveries ranged from $89 \%$ to $118 \%$ for all elements. Duplicate samples were analyzed synchronously for $15 \%$ of the samples and the standard deviation was controlled within $5 \%$ in each digestion procedure.

\section{Estimation of Dust Enrichment}

\section{Enrichment Factor}

Enrichment factor (Ef) is currently performed to assess the degree of heavy element in environmental media [27-28]. It is calculated using the following formula [18]:

$$
\mathrm{Ef}=\left[\mathrm{X}_{\mathrm{s}} / \mathrm{E}_{\mathrm{s}}\right] /\left[\mathrm{X}_{\mathrm{r}} / \mathrm{E}_{\mathrm{r}}\right]
$$

...where $\left[\mathrm{X}_{\mathrm{s}} / \mathrm{E}_{\mathrm{s}}\right]$ is the ratio of concentration of element $\mathrm{X}_{\mathrm{s}}$ to that of normalizer element $\mathrm{E}_{\mathrm{s}}$ in street dust and $\left[\mathrm{X}_{\mathrm{r}} / \mathrm{E}_{\mathrm{r}}\right]$ is the same reference ratio in the earth crust. In this study, Ti was used as the normalizer element due to its natural origin being found in a previous study [29]. The background concentrations of soil heavy elements in Nanchang instead of the crustal element concentration were applied in this study in order to reduce the effects of natural geochemical variability [30]. The Ef classification is listed in Table S3 [31].

\section{Modified Degree of Contamination $\left(\mathrm{mC}_{\mathrm{d}}\right)$}

The degree of contamination $\left(\mathrm{C}_{\mathrm{d}}\right)$ was initially raised by Hakanson in order to evaluate the degree of 
overall contamination suffered from eight pollutants (PCB, $\mathrm{Hg}, \mathrm{Cd}, \mathrm{As}, \mathrm{Cu}, \mathrm{Pb}, \mathrm{Cr}$, and $\mathrm{Zn}$ ) [32]. Abrahim modified $\mathrm{C}_{\mathrm{d}}$ as the quotient being equal to the sum of all the contamination factors $(\mathrm{CF})$ (the ratio of pollutant concentration to that in the background environment) for given pollutants divided by the number of analyzed pollutants, which allowed for the extension from eight pollutants to more pollutants with no upper limit [33]. In this study, CF is replaced by Ef in order to evaluate the $\mathrm{C}_{d}$ of street dust in a specific site. The equation of modified degree of contamination $\left(\mathrm{mC}_{\mathrm{d}}\right)$ is given below:

$$
m C_{d}=\frac{\sum_{i=1}^{n} E f^{i}}{n}
$$

...where $\mathrm{n}$ is the number of analyzed elements. The classification of $\mathrm{mC}_{\mathrm{d}}$ was the same as $\mathrm{Ef}$ and presented in Table S3.

\section{Health Risk Assessment}

The health risk assessment mode, raised by the United States Environmental Protection Agency [34], was widely used to evaluate human health risk (carcinogenic and non-carcinogenic) exposure to pollutants in various media [18, 35-36]. Direct ingestion, inhalation and dermal contact were the common exposure pathways into the human body. The average daily dose (ADD) (mg kg-1 day $\left.{ }^{-1}\right)$ for heavy elements through the above three pathways was calculated as follows:

$$
\begin{gathered}
\mathrm{ADD}_{\text {ing }}=\frac{C_{U C L} \times I n g R \times E F \times E D}{B W \times A T} \\
A D D_{\text {inh }}=\frac{C_{U C L} \times I n h R \times \mathrm{EF} \times \mathrm{ED}}{P E F \times B W \times A T} \\
A D D_{\text {dermal }}=\frac{C_{U C L} \times S A \times C F \times A F \times A B F \times E F \times E D}{B W \times A T}
\end{gathered}
$$

...where $A D D_{\text {ing }}, A D D_{i n h}$, and $A D D_{\text {dermal }}$ are ADD for ingestion, inhalation and dermal contact, respectively. $C_{U C L}$ is the upper limit of the $95 \%$ confidence interval for the mean to yield an estimate of reasonable maximum exposure [37]. The other variables used in these equations are specified in Table S4.

Hazards quotient (HQ), hazard index (HI), and carcinogenic risks (CR) were employed to understand the health risks due to element exposure in environmental media. The HI represents the non-carcinogenic risk to estimates of the probability of developing illness except cancer, while CR calculates the probability of developing cancer in an individual from exposure to heavy elements [14]. These indexes were calculated for an individual using the following equations $[14,38]$ :

$$
\mathrm{HQ}=A D D / R_{f} D
$$

$$
\begin{gathered}
\mathrm{HI}=\sum H Q_{\text {ing } / \text { inh } / \text { dermal }} \\
\mathrm{CR}=\sum A D D \times S F
\end{gathered}
$$

...where $\mathrm{R}_{\mathrm{f}} \mathrm{D}$ and $\mathrm{SF}$ (dimensionless) are reference dose and carcinogenic slope factor, respectively. HI is the sum of HQs for each exposure pathway. $\mathrm{HI}<1$ indicates the low non-carcinogenic risk, while HI $>1$ shows the serious risk [39]. The tolerance limit value of $\mathrm{CR}$ for regulatory purposes falls in the range of $10^{-6}-10^{-4}$ [18].

\section{Statistical Analysis}

The descriptive data was analyzed statistically with PASW Statistics 18 software (SPSS Inc., Chicago, IL, USA). Multivariate analysis of variance (MANOVA) was applied to analyze the interaction of seasons and areas on concentrations of heavy elements in street dust. Correlation analysis for relationships among heavy elements was conducted in R package. All graphs were plotted using Origin 9.0 (Origin Lab Corporation, Northampton, Massachusetts, USA).

\section{Results and Discussion}

\section{Heavy Element Concentrations in Street Dusts of Nanchang}

The concentrations of heavy element in street dusts are summarized in Table 1. By comparison, mean concentrations of $\mathrm{Ti}, \mathrm{Sc}, \mathrm{Ga}, \mathrm{Rb}, \mathrm{Cs}$, and $\mathrm{Tl}$ were lower than their corresponding background values of soil, while mean concentrations of $\mathrm{Cr}, \mathrm{Cu}, \mathrm{Zn}, \mathrm{Cd}$, and $\mathrm{Pb}$ greatly exceeded their corresponding background values of soil. Furthermore, it was found that $\mathrm{Cu}, \mathrm{Zn}$, $\mathrm{Cd}$, and $\mathrm{Pb}$ levels were even more than 2 times higher than their soil background values. A similar result was also reported in [40]. These elements were always derived from urban anthropogenic sources such as vehicular traffic, industrial plants, city construction and demolition activities, especially for $\mathrm{Cd}$ and $\mathrm{Pb}$ [41]. It is worth noting that mean concentrations of $\mathrm{Sr}, \mathrm{Te}, \mathrm{Ba}, \mathrm{Sn}$, $\mathrm{Sb}$, and $\mathrm{Bi}$ exceed corresponding soil background values, which indicate anthropogenic input. This was especially true for $\mathrm{Sr}$ and $\mathrm{Sb}$, which were on average 6.79 and 8.82 times their background values, respectively. These elements in dust received little attention in the previous studies and the specific source was scarcely reported. Only Ali et al. reported Sb and Sn in the street dust, possibly derived from the smelter industry [22]. The rest of the metals, including $\mathrm{Li}, \mathrm{V}, \mathrm{Co}, \mathrm{Ni}, \mathrm{As}$, and $\mathrm{W}$, exceeded their corresponding background values in some area or season (Table 1).

The interactive influences from areas and seasons on element concentrations in the street dust are shown in Table S5. It was found that concentrations of most elements had high spatial variation, except $\mathrm{Li}, \mathrm{Sc}, \mathrm{Sr}$, 
Table 1. Mean \pm standard deviation of element in street dusts in Nanchang, China $\left(\mathrm{mg} \mathrm{kg}^{-1}\right)$

\begin{tabular}{|c|c|c|c|c|c|c|c|}
\hline \multirow{2}{*}{ Elements } & \multicolumn{2}{|c|}{ Center } & \multicolumn{2}{|c|}{ Extension } & \multicolumn{2}{|c|}{ Fringe } & \multirow{2}{*}{$\begin{array}{c}\text { Background } \\
\text { Values }\end{array}$} \\
\hline & Summer & Winter & Summer & Winter & Summer & Winter & \\
\hline $\mathrm{Ti}$ & $2902 \pm 351.1$ & $3087 \pm 317.1$ & $3099 \pm 613.2$ & $3043 \pm 458.0$ & $3671 \pm 611.1$ & $2967 \pm 336.6$ & 4400 \\
\hline $\mathrm{Li}$ & $29.37 \pm 6.03$ & $66.52 \pm 82.70$ & $43.68 \pm 61.77$ & $47.44 \pm 16.55$ & $35.63 \pm 4.20$ & $36.53 \pm 4.23$ & 45.1 \\
\hline $\mathrm{Sc}$ & $5.860 \pm 0.828$ & $7.193 \pm 2.972$ & $6.785 \pm 2.647$ & $6.478 \pm 1.028$ & $7.045 \pm 0.957$ & $6.227 \pm 0.897$ & 10.31 \\
\hline V & $58.47 \pm 5.32$ & $59.01 \pm 9.10$ & $140.00 \pm 77.43$ & $101.41 \pm 42.28$ & $81.28 \pm 24.28$ & $71.76 \pm 15.55$ & 92.13 \\
\hline $\mathrm{Cr}$ & $122.5 \pm 30.67$ & $152.4 \pm 121.58$ & $95.57 \pm 27.30$ & $108.4 \pm 33.39$ & $89.21 \pm 23.95$ & $103.5 \pm 74.4$ & 60.74 \\
\hline Co & $8.66 \pm 0.99$ & $10.26 \pm 2.16$ & $13.68 \pm 5.99$ & $10.66 \pm 2.04$ & $8.934 \pm 1.700$ & $8.751 \pm 2.319$ & 12.17 \\
\hline $\mathrm{Ni}$ & $31.55 \pm 10.33$ & $35.64 \pm 23.24$ & $29.58 \pm 10.29$ & $25.88 \pm 8.79$ & $22.21 \pm 8.59$ & $20.17 \pm 8.10$ & 20.96 \\
\hline $\mathrm{Cu}$ & $94.30 \pm 30.95$ & $128.68 \pm 70.79$ & $110.1 \pm 67.31$ & $87.61 \pm 39.83$ & $66.01 \pm 34.26$ & $63.11 \pm 25.87$ & 20.1 \\
\hline $\mathrm{Zn}$ & $352.5 \pm 241.5$ & $345.1 \pm 137.7$ & $263.5 \pm 99.99$ & $251.0 \pm 78.63$ & $309.2 \pm 317.3$ & $246.2 \pm 141$ & 64.37 \\
\hline $\mathrm{Ga}$ & $9.666 \pm 1.149$ & $10.57 \pm 1.634$ & $11.50 \pm 1.83$ & $11.00 \pm 1.46$ & $10.78 \pm 1.12$ & $10.08 \pm 1.15$ & 20.00 \\
\hline As & $7.808 \pm 1.511$ & $10.13 \pm 2.976$ & $14.74 \pm 12.38$ & $11.69 \pm 5.05$ & $8.209 \pm 1.86$ & $9.696 \pm 5.14$ & 11.12 \\
\hline $\mathrm{Rb}$ & $107.2 \pm 9.984$ & $112.2 \pm 14.22$ & $94.41 \pm 16.04$ & $108.67 \pm 11.43$ & $103.2 \pm 12.0$ & $110.9 \pm 10.6$ & 174 \\
\hline $\mathrm{Sr}$ & $223.6 \pm 86.32$ & $250.7 \pm 105.1$ & $216.84 \pm 83.83$ & $244.17 \pm 61.95$ & $225.3 \pm 76.3$ & $264.8 \pm 85.8$ & 35 \\
\hline $\mathrm{Cd}$ & $0.677 \pm 0.251$ & $0.802 \pm 0.306$ & $0.890 \pm 0.868$ & $1.452 \pm 1.301$ & $1.070 \pm 0.889$ & $1.036 \pm 0.564$ & 0.11 \\
\hline $\mathrm{Sn}$ & $16.71 \pm 11.15$ & $17.76 \pm 10.53$ & $10.28 \pm 4.53$ & $10.05 \pm 3.36$ & $10.29 \pm 4.78$ & $8.508 \pm 2.21$ & 6.4 \\
\hline $\mathrm{Sb}$ & $8.327 \pm 2.575$ & $10.059 \pm 4.869$ & $7.323 \pm 3.665$ & $8.095 \pm 2.703$ & $9.442 \pm 3.87$ & $9.667 \pm 3.07$ & 1.15 \\
\hline $\mathrm{Te}$ & $0.111 \pm 0.027$ & $0.143 \pm 0.044$ & $0.240 \pm 0.245$ & $0.173 \pm 0.073$ & $0.107 \pm 0.056$ & $0.135 \pm 0.077$ & 0.042 \\
\hline Cs & $5.538 \pm 0.802$ & $6.720 \pm 2.249$ & $5.792 \pm 1.986$ & $6.426 \pm 0.755$ & $6.120 \pm 0.696$ & $6.400 \pm 1.81$ & 12.99 \\
\hline $\mathrm{Ba}$ & $560.9 \pm 62.62$ & $630.7 \pm 254.7$ & $627.2 \pm 183.9$ & $645.4 \pm 122.6$ & $715.7 \pm 184$ & $731.2 \pm 157$ & 345 \\
\hline W & $5.424 \pm 2.363$ & $8.659 \pm 9.133$ & $5.018 \pm 2.219$ & $6.516 \pm 2.554$ & $10.11 \pm 14.7$ & $8.668 \pm 8.04$ & 5.28 \\
\hline $\mathrm{Tl}$ & $0.537 \pm 0.051$ & $0.588 \pm 0.065$ & $0.540 \pm 0.157$ & $0.608 \pm 0.844$ & $0.604 \pm 0.064$ & $0.640 \pm 0.077$ & 0.875 \\
\hline $\mathrm{Pb}$ & $72.53 \pm 38.89$ & $93.15 \pm 43.46$ & $98.57 \pm 96.21$ & $118.7 \pm 107.5$ & $97.31 \pm 71.7$ & $88.41 \pm 34.6$ & 29.64 \\
\hline $\mathrm{Bi}$ & $1.226 \pm 0.759$ & $1.560 \pm 1.044$ & $2.498 \pm 2.929$ & $1.669 \pm 0.651$ & $1.419 \pm 1.28$ & $1.197 \pm 0.914$ & 0.89 \\
\hline
\end{tabular}

$\mathrm{Cs}, \mathrm{W}$, and $\mathrm{Pb}$. In the case of $\mathrm{Cr}, \mathrm{Ni}, \mathrm{Cu}, \mathrm{Zn}, \mathrm{Sn}$, and $\mathrm{Sb}$, the mean concentrations were highest in the center area, while some elements such as V, Co, As, Cd, Te, and $\mathrm{Bi}$ had the highest levels in the extension area (Table 1). The previous studies found that the street dust from industrial and urban areas had high levels of heavy elements, while the dust from the peri-urban area always had the lowest mean values of heavy elements [22]. Most heavy elements had similar spatial variation from the center area to the fringe area, except $\mathrm{Cd}, \mathrm{Sb}, \mathrm{Ba}$, and $\mathrm{W}$. The high levels of $\mathrm{Cd}$ and $\mathrm{Sb}$ in the fringe area indicated their varied sources [41, 42-43]. The effect of seasons on element concentrations was far less than that of areas (Table S5). Only concentrations of Ti, V, Rb, Sr, Cs, and $\mathrm{Tl}$ had significant seasonal variations. Gope et al. also found that concentrations of some elements such as As, $\mathrm{Cd}, \mathrm{Co}, \mathrm{Cr}, \mathrm{Cu}, \mathrm{Ni}$, and $\mathrm{Pb}$ had no significant differences between summer and winter [18]. Oppositely, Men et al. found that the concentrations of $\mathrm{As}, \mathrm{Cd}, \mathrm{Cr}, \mathrm{Cu}$, and $\mathrm{Pb}$ had significant seasonal differences [4]. These different conclusions indicated the uncertainty of effects of seasonal variations on concentrations of heavy elements in street dusts. The interactive influences from areas and seasons on concentrations of elements in street dust only happened on $\mathrm{Ti}, \mathrm{Sc}, \mathrm{V}, \mathrm{Cu}$, and $\mathrm{Ga}$.

A comparison of the results with those reported in literature for the heavy elements in street dusts from other cities is presented in Table S6. Most comparisons only happened on some common potential toxic elements such as $\mathrm{V}, \mathrm{Cr}, \mathrm{Co}, \mathrm{Ni}, \mathrm{Cu}, \mathrm{Zn}, \mathrm{As}, \mathrm{Cd}$, and $\mathrm{Pb}$. The investigated elements in dust samples from Nanchang city did not present distinct concentration characteristics compared to those in other cities except $\mathrm{V}$. The high $\mathrm{V}$ level in street dust from Nanchang was possibly due to its high background value (92.13 $\mathrm{mg} / \mathrm{kg}$ ) (Table 1). The concentrations of investigated elements in street dusts were almost similar to those of Chengdu, China [21]. It was not suitable for comparison of element concentrations between Guangzhou, Chongqing and Nanchang (this study) due to their different particle sizes. Different particle sizes always resulted in different levels of heavy 


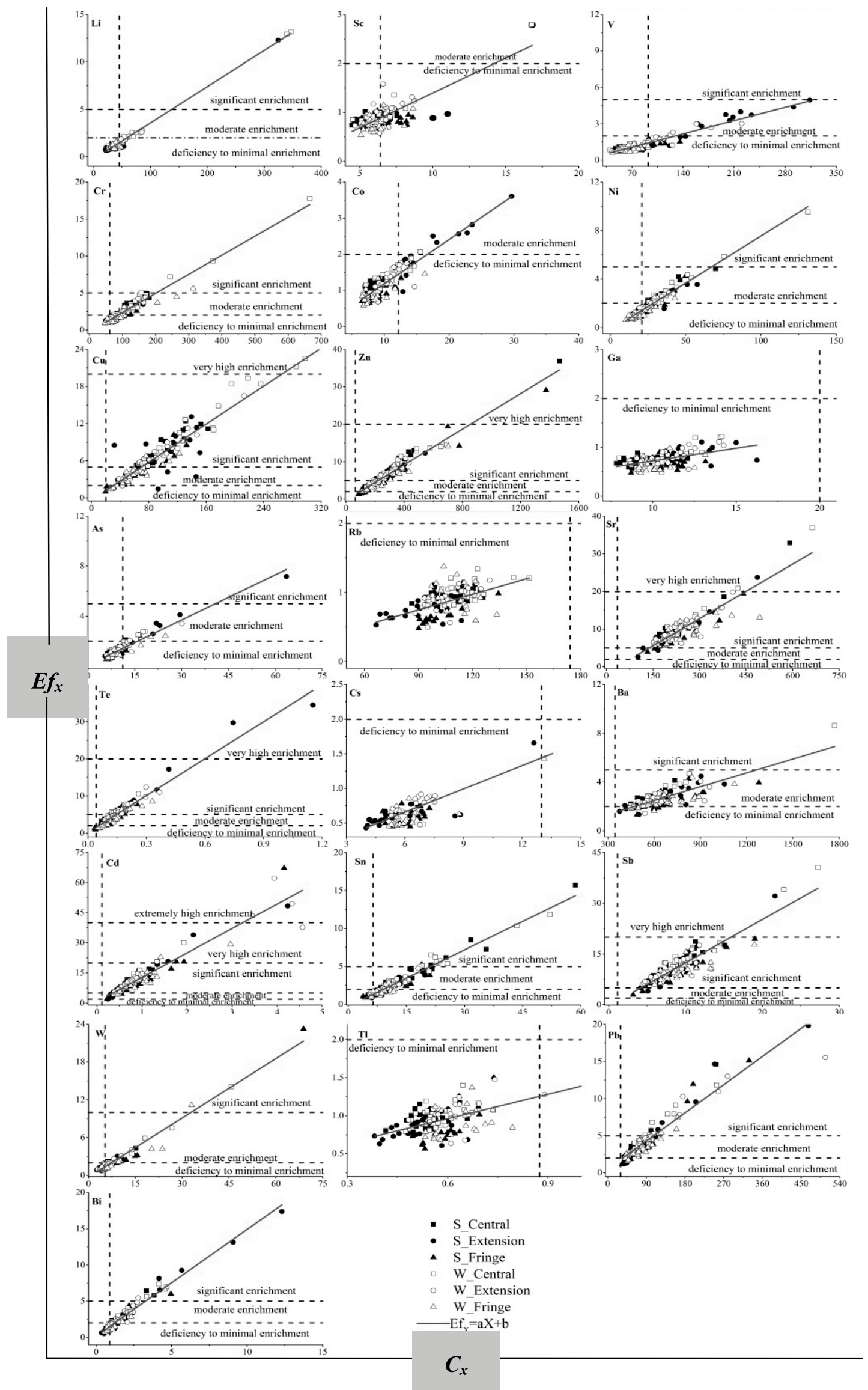

Fig. 2. Environmental factor (Ef) of elements in street dusts in the center, extension and fringe areas from Nanchang, China $\left(C_{x}\right.$ is the concentration of element X; horizontal dash represents the different level of risk; vertical dash shows the background value of corresponding element; S represents summer; W represents winter). 
element enrichment [44]. The comparison of element concentrations among different seasons also needed to be interpreted with caution by reason of significant seasonality of element concentrations in some studies [4].

\section{Pollution Assessment of Heavy Elements in Street Dusts}

The pollution of 22 heavy elements in street dust of Nanchang was evaluated using the enrichment factor (Ef). This method is applied widely in order to evaluate the pollution level of heavy elements and can also be used for distinguishing the anthropogenic source or natural origin $[27,29]$. The Ef values of heavy elements are shown in Fig. 2. In general, the Ef value for $\mathrm{Sc}, \mathrm{Ga}$, $\mathrm{Rb}, \mathrm{Cs}, \mathrm{Tl}$ were $<2$, which indicated that there was no pollution in case of these elements. On the contrary, most Ef values for $\mathrm{Cu}, \mathrm{Zn}, \mathrm{Sr}, \mathrm{Te}, \mathrm{Ba}, \mathrm{Cd}, \mathrm{Sn}, \mathrm{Sb}, \mathrm{Pb}$, and $\mathrm{Bi}$ exceeded 2, which indicated there was moderate enrichment in case of these elements. Especially for $\mathrm{Cd}$, some Ef values $>40$ indicated extremely high enrichment. Almost all Ef values for $\mathrm{Cu}, \mathrm{Zn}, \mathrm{Sr}, \mathrm{Cd}$, and $\mathrm{Sb}$ were $>2$, which suggested that the street dust in Nanchang city was moderately contaminated by these elements. Saeedi et al. found that heavy elements in dusts with maximum Ef values $>10$ were mainly derived from anthropogenic activities [45]. Therefore, heavy elements in street dust such as $\mathrm{Cr}, \mathrm{Ni}, \mathrm{Cu}, \mathrm{Zn}, \mathrm{Sr}, \mathrm{Te}, \mathrm{Cd}$, $\mathrm{Sn}, \mathrm{Sb}, \mathrm{W}, \mathrm{Pb}$, and $\mathrm{Bi}$ in this study had anthropogenic footprints. The high $\mathrm{Ef}$ values of $\mathrm{Cd}$ were almost found in all other cities $[18,21]$. And $\mathrm{Cd}$ had been regarded as the anthropogenic-related element in city environment $[7,14,44]$. Ali et al. also evaluated the pollution levels of $\mathrm{Sn}, \mathrm{Sb}$, and $\mathrm{Ga}$ in street dust and found that these elements had high pollution levels [22]. High pollution levels of $\mathrm{Sn}$ and $\mathrm{Sb}$ were also found in this study.
However, the pollution level of Ga was relatively low in this study. This comparison suggested that $\mathrm{Sn}$ and $\mathrm{Sb}$ were also common urban pollutants, just like $\mathrm{Cu}, \mathrm{Zn}$, $\mathrm{Pb}$, and $\mathrm{Cd}$, while $\mathrm{Ga}$ was an exclusive pollutant relating to urban characteristics [22]. Other elements such as $\mathrm{Sr}$ and Te also had high pollution levels in our study, which were not found in previous studies. The Ef values of heavy element were distributed randomly and did not show obvious spatial-temporal characteristics (Fig. 2).

To further evaluate the pollution levels of heavy elements in street dusts in different areas and seasons, the $\mathrm{mC}_{\mathrm{d}}$ was calculated and shown in Fig. 3. The $\mathrm{mC}_{\mathrm{d}}$ presented the total Ef of heavy elements in environments without regard to the antagonism or mutualism among elements $[28,46]$. All $\mathrm{mC}_{\mathrm{d}}$ values for heavy elements at center, extension, and fringe area with two seasons ranged from 2 to 5 , which suggested that the street dusts in Nanchang suffered from moderate enrichment by heavy elements. The $\mathrm{mC}_{\mathrm{d}}$ values among three areas in winter had no significant difference, while it decreased significantly from the center area to the fringe area in summer. The enrichment of heavy elements at the center street dusts in winter had significantly higher levels than in summer. The seasonality suggested that more pollution sources at center area in winter enhanced the high levels of element emission [47-49]. Additionally, the seasonality of meteorological parameters also affected the enrichment of heavy elements in dust [50]. Precipitation with high amounts and intensities easily carried fine particulates from surface dusts and resulted in the decline of element levels in dusts, while light precipitation prevented fine particulate resuspension in atmosphere and the pollutants in dust migration because of the lack of effective runoff [50]. Both amount and intensity of precipitation of Nanchang in summer was clearly higher than those in winter (Table S1) [51]. Therefore, this situation consequentially resulted in

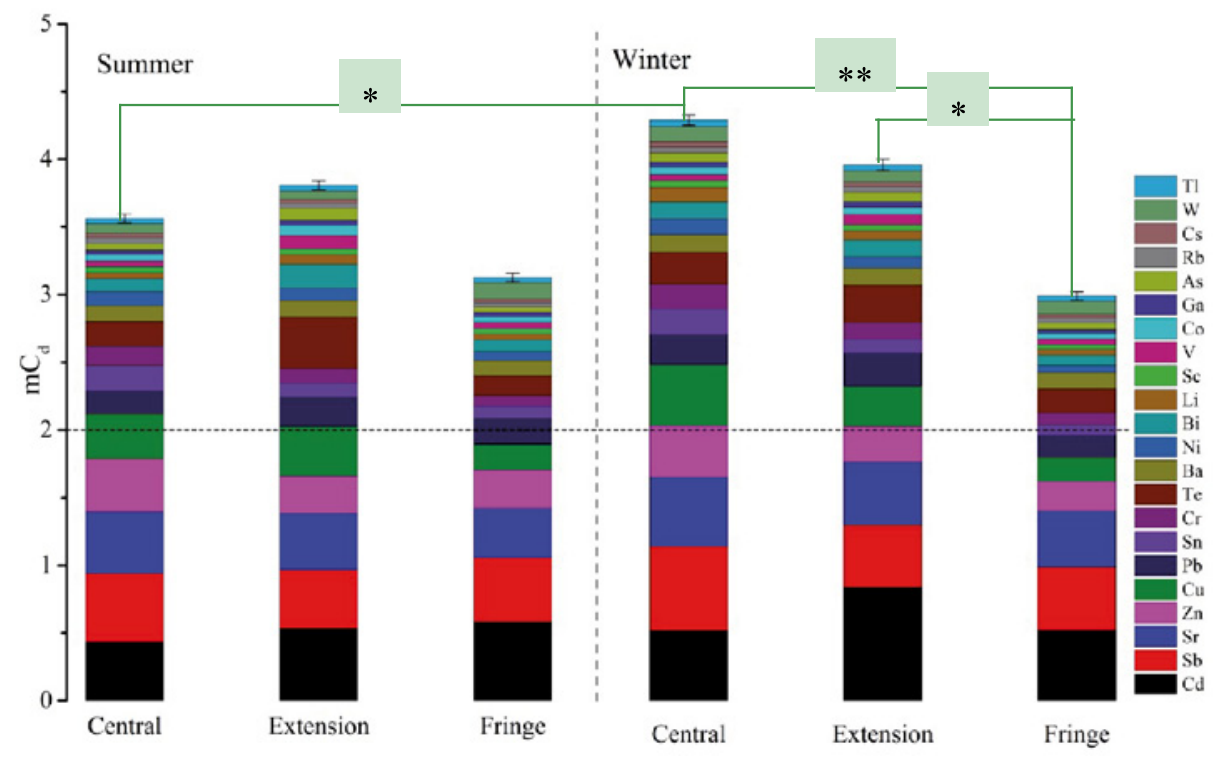

Fig. 3. $\mathrm{mC}_{\mathrm{d}}$ (mean \pm standard error) values of the 22 heavy elements in street dusts from Nanchang in the different areas and seasons. 
the higher element enrichments in winter than in summer. The "rain inland" effect in summer prompted the significantly lower element enrichment in the center area than in winter [51]. The sum Ef of $\mathrm{Cd}, \mathrm{Sr}$, and $\mathrm{Sb}$ in the street dusts in Nanchang accounted for 36.38-46.96\% of total Ef. Therefore, these metals in street dusts in Nanchang should be viewed as priority pollutants.
Relationships among Heavy Elements from the Center to the Fringe

An average Ef greater than 2 indicated that the elements in the environments were affected by anthropogenic inputs [28, 31]. Therefore, heavy elements in street dust from different areas with Ef

a)

\begin{tabular}{|c|c|c|c|c|c|c|c|c|c|c|c|c|}
\hline The & 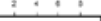 & & 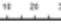 & & & & ב & & 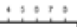 & & 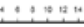 & \\
\hline Ih $\mathrm{cr}$ & $0.74^{\prime \prime}$ & oes " & 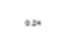 & $\cdots$ & $\because$ & : & - & - & $\therefore$ & $0.70^{\circ}$ & $\ldots$ & - \\
\hline & & ${ }_{0 \leq 3} \cdots$ & $: x$ & .. & ${ }^{\circ}$ &.${ }^{*}$ & .. & $\cdots$ & « & ${ }_{0.10}^{\circ}$ & $x$ & $\cdots$ \\
\hline & $\ddot{4}$ & $\pi^{c u}$ & $s$ & 02. & ${ }_{0.3+}$ & ${ }_{0.40} \cdots$ & $"$ & ד & ${ }_{0 . y} "$ & $\because$ & 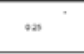 & ${ }_{\text {ost }}$ " \\
\hline & & & & $"$ & ${ }_{0.55}{ }^{-\cdots}$ & an & $\because$ & $\infty^{\circ}$ & $x^{\circ}$ & $\cdot$ & ${ }^{\circ x^{\circ}}$ & ". \\
\hline & $\Rightarrow$ & $\therefore \therefore$ & $s$ & st & $m^{*}$ & $\infty$ & $\because$ &. & ${ }_{052} \cdots$ & $\because$ & $\sim$ & -" \\
\hline & $y$ & & $x$ & 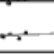 & la. & : & $0.80^{\prime \prime}$ & $0.58 \cdots$ & ${ }_{0.10} "$ & - & ${ }_{0.50} \cdots$ & 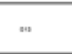 \\
\hline & & & & r. & & & $=$ & $\therefore$ & - & - & ${ }_{0.55}{ }^{\prime \prime}$ & $\therefore *^{*}$ \\
\hline & 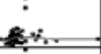 & 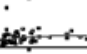 & 4 & $\because \cdot$ & a. & $\therefore$ & $n_{m .}^{s b}$ & a.6. $\cdots$ & $\infty^{\circ}$ & - & 0.41 " & .. \\
\hline & s: & in & 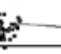 & $\therefore$ & 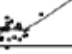 & s.... & $\%$ & I. & e. & - & .os $\cdots$ & ${ }^{0 x}$ \\
\hline & $\infty$ & $\Delta i$ & & 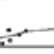 & . & $2 \mathrm{in}:-$. & per & man & Ba & 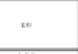 & ... & - \\
\hline & & 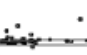 & & $\therefore$ & $\therefore$ & & $\vdots$ & $\therefore$ & . & w & - & - \\
\hline & & & & & & & & & & & & $\frac{-}{-\overline{B i}}$ \\
\hline
\end{tabular}

b)

\begin{tabular}{|c|c|c|c|c|c|c|c|c|c|c|}
\hline - & $a r$ & $0.58 s^{n+m}$ & $\cdots$ & 0.44 & 0.49 & e.z & ex & “* & $\infty$ & $\infty \cdots$ \\
\hline$\therefore$ & $C^{\text {cu }}$ & $0.51 \cdots$ & - & - & ${ }_{0.56}{ }^{\circ}$ & - & ... & - & 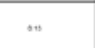 & $\cdots$ \\
\hline & & lib & $\cdots$ & o. & $0.60^{\cdots}$ & 0.3 & $a$ & - & $w$ & $\infty \infty$ \\
\hline 92 & $\Leftrightarrow$ & . & $\mathrm{fl}^{\mathrm{si}}$ & - & - & 0.54 & - & $0.63{ }^{\cdots} \cdots$ & $\cdots$ & $\therefore$ \\
\hline & & & $\because$ & $c d$ & 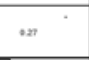 & 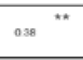 & 0.49 & - & $0.83^{\text {tnk }}$ & 0.45 \\
\hline & & 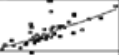 & 3 & & enting & $\cdots$ & azt & “. & $\infty{ }^{*}$ & ${ }_{0 \times}^{*}$ \\
\hline & & & & & $\therefore$ & 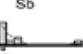 & 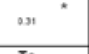 & $\alpha x^{*}$ & o* & .. \\
\hline 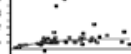 & & & & & & & & * & $0.566^{-m}$ & $0.59^{\cdots \cdots}$ \\
\hline & & & $\because$ & & $\because$ & 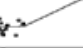 & & Plo & A & A \\
\hline$\because$ & $\therefore$. & $\because \because$ & & & & & & & $\mathrm{Pb}$ & $0.60^{\cdots \cdots}$ \\
\hline$\therefore$ & $\therefore$ & & 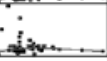 & & & & & . & & ${ }^{8 i}$ \\
\hline
\end{tabular}

c)

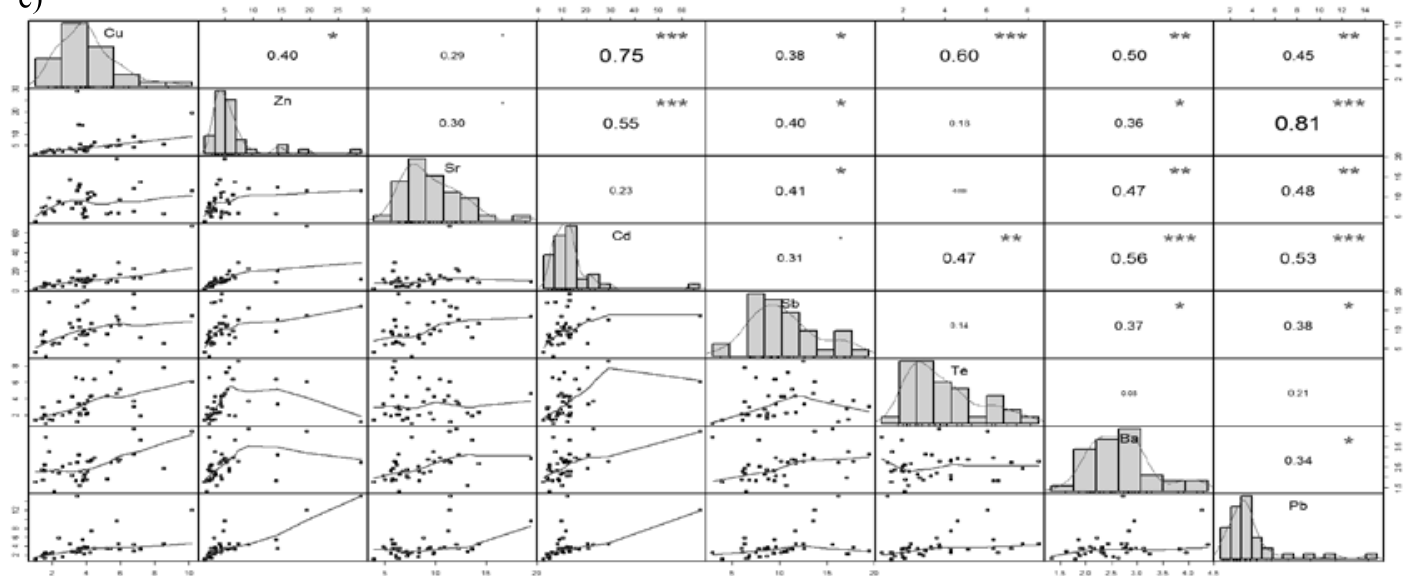

Fig. 4. Correlation matrix among heavy elements in street dusts in the center a), expansion b), and fringe c) areas in Nanchang; the number in the grid with probability distribution graph refers to the average Ef of the element. 
higher than 2 were chosen in order to understand their interrelationships. The interrelationships among heavy elements in street dusts from different areas are shown in Fig. 4. Concentrations and geo-accumulation index $\left(\mathrm{I}_{\text {geo }}\right)$ were always regarded as the indicators of anthropogenic activities from urban area to peri-urban area [4, 22]. It was noteworthy that the average Efs of 13, 11, and 8 elements in dusts in our study were higher than 2 in center, extension, and fringe areas, respectively. The change of element $(\mathrm{Ef}>2)$ number from center to fringe was consistent with the change of population density and traffic flow (Table S2). Therefore, the number of trace heavy elements influenced by anthropogenic activities also could be identified as an indicator of urban expansion. Specifically, the Efs of elements such as $\mathrm{Cr}, \mathrm{Ni}, \mathrm{Sn}$, and $\mathrm{W}$ also decreased from the center to the fringe area. Therefore, those elements also could be regarded as indicators of urban expansion.

As shown in Fig. 4, $\mathrm{Cd}$ and $\mathrm{Pb}$ had significant positive correlation with most elements in all three areas. Positive correlated elements were always deemed as having similar sources, accumulation and transport [18]. Therefore, these two elements could be served as the representative individuals to identify the sources of elements in the street dusts in Nanchang. Lead was the symbolic element of the traffic and mainly derived from exhaust, tyres, and lubricant [18, 21, 52]. Most metals correlated with $\mathrm{Pb}$, suggesting their traffic source. Cadmium had been regarded as the anthropogenic- related element in a city environment and derived from diverse sources such as paints, building materials, platting industry, batteries, plastic, and fertilizer [29, 41, 53-55], which indicated that most metals had varied sources. Barium was reported to have high correlation with metal smelting in a previous study [29]. It was noteworthy that $\mathrm{Ba}$ and $\mathrm{Sr}$ correlated well in three areas, which were regarded as the indicators of metal smelting. Cadmium and Te were the typical elements related to coal combustion [29, 47]. Antimony had high correlation with $\mathrm{Cd}$ and $\mathrm{Te}, \mathrm{Sr}$ and $\mathrm{Ba}, \mathrm{Zn}$ and $\mathrm{Pb}$ at center area, extension area, and fringe area, respectively, which suggested that the varied sources of $\mathrm{Sb}$ varied in different areas. It was also found that the correlation coefficients among the same elements varied in different areas, possibly due to the different contributions of the pollutant sources [56]. There were high correlations between $\mathrm{Pb}$ and other elements in the fringe area, which indicated that traffic accounted for the majorities of elements in street dusts.

\section{Human Health Risk Assessment}

The HQ values were calculated to evaluate the human health risk (non-carcinogenic) from heavy element exposure through dust in three areas and two seasons (Table S5 and S6). The $\mathrm{HQ}_{\text {ing }}$ values for all the elements in all areas and two seasons were below 1, which suggested that the non-carcinogenic hazard via

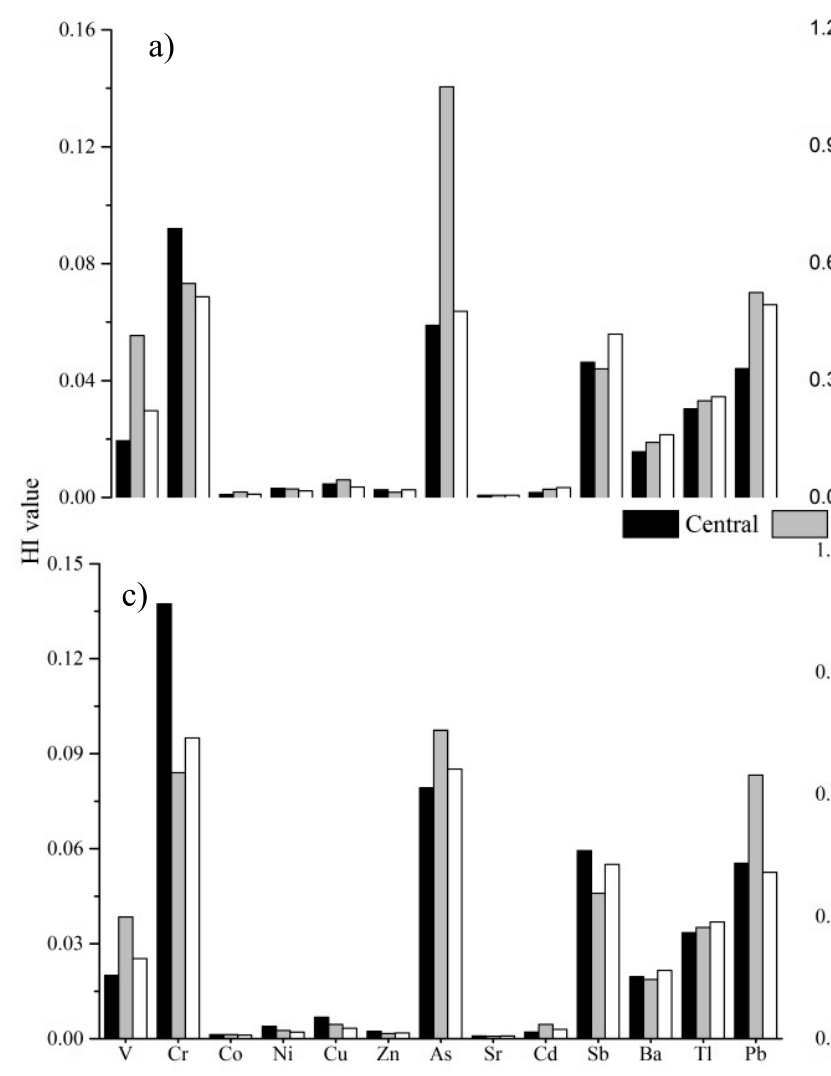

b)

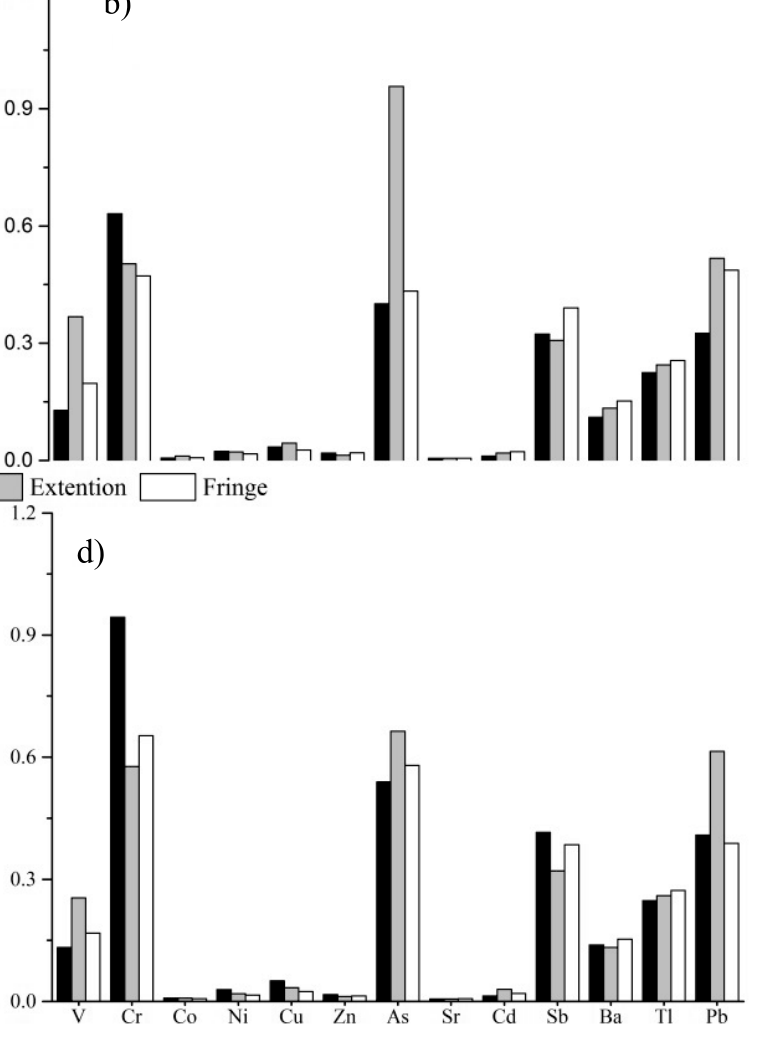

Fig. 5. HI ( $\sum \mathrm{HQ}$ ) for a) adult and b) children in summer and c) adult and d) children in winter at the center, extension and fringe areas of Nanchang, China. 
Table 2. Lifetime carcinogenic risk (CR) of heavy elements for children and adults at different areas in two seasons.

\begin{tabular}{|c|c|c|c|c|c|c|c|c|c|c|}
\hline \multirow{2}{*}{ Seasons } & \multirow{2}{*}{ Elements } & \multirow{2}{*}{$\mathrm{SF}_{\text {ing }}$} & \multirow{2}{*}{$\mathrm{SF}_{\mathrm{inh}}$} & \multirow{2}{*}{$\mathrm{SF}_{\text {dermal }}$} & \multicolumn{2}{|c|}{ Central } & \multicolumn{2}{|c|}{ Extension } & \multicolumn{2}{|c|}{ Fringe } \\
\hline & & & & & Children & Adults & Children & Adults & Children & Adults \\
\hline \multirow{5}{*}{ Summer } & $\mathrm{Cr}$ & & $4.02 \mathrm{E}+01$ & & $2.03 \mathrm{E}-06$ & $9.15 \mathrm{E}-07$ & $1.62 \mathrm{E}-06$ & $7.28 \mathrm{E}-07$ & $1.52 \mathrm{E}-06$ & $6.83 \mathrm{E}-07$ \\
\hline & $\mathrm{Co}$ & & $9.80 \mathrm{E}+00$ & & $3.18 \mathrm{E}-08$ & $1.43 \mathrm{E}-08$ & $5.72 \mathrm{E}-08$ & $2.57 \mathrm{E}-08$ & $3.43 \mathrm{E}-08$ & $1.54 \mathrm{E}-08$ \\
\hline & $\mathrm{Ni}$ & & $8.40 \mathrm{E}-01$ & & $1.08 \mathrm{E}-08$ & 4.84E-09 & $1.03 \mathrm{E}-08$ & 4.62E-09 & 7.94E-09 & $3.57 \mathrm{E}-09$ \\
\hline & As & $1.50 \mathrm{E}+00$ & $1.51 \mathrm{E}+01$ & $3.66 \mathrm{E}+00$ & $1.80 \mathrm{E}-04$ & $2.65 \mathrm{E}-05$ & $4.31 \mathrm{E}-04$ & $6.33 \mathrm{E}-05$ & $1.95 \mathrm{E}-04$ & $2.87 \mathrm{E}-05$ \\
\hline & $\mathrm{Cd}$ & & $6.30 \mathrm{E}+00$ & & $1.76 \mathrm{E}-09$ & $7.91 \mathrm{E}-10$ & $2.86 \mathrm{E}-09$ & 1.29E-09 & 3.39E-09 & $1.52 \mathrm{E}-09$ \\
\hline \multirow{5}{*}{ Winter } & $\mathrm{Cr}$ & & $4.02 \mathrm{E}+01$ & & $3.04 \mathrm{E}-06$ & $1.37 \mathrm{E}-06$ & $1.86 \mathrm{E}-06$ & $8.35 \mathrm{E}-07$ & $2.10 \mathrm{E}-06$ & $9.45 \mathrm{E}-07$ \\
\hline & $\mathrm{Co}$ & & $9.80 \mathrm{E}+00$ & & 3.91E-08 & $1.76 \mathrm{E}-08$ & 4.07E-08 & $1.83 \mathrm{E}-08$ & $3.47 \mathrm{E}-08$ & $1.56 \mathrm{E}-08$ \\
\hline & $\mathrm{Ni}$ & & $8.40-01$ & & $1.36 \mathrm{E}-08$ & $6.11 \mathrm{E}-09$ & 8.97E-09 & 4.04E-09 & $7.25 \mathrm{E}-09$ & $3.26 \mathrm{E}-09$ \\
\hline & As & $1.50 \mathrm{E}+00$ & $1.51 \mathrm{E}+01$ & $3.66 \mathrm{E}+00$ & $2.43 \mathrm{E}-04$ & $3.54 \mathrm{E}-05$ & 2.99E-04 & 4.39E-05 & $2.61 \mathrm{E}-04$ & $3.83 \mathrm{E}-05$ \\
\hline & $\mathrm{Cd}$ & & $6.30 \mathrm{E}+00$ & & 2.09E-09 & $9.41 \mathrm{E}-10$ & 4.59E-09 & $2.06 \mathrm{E}-09$ & $2.96 \mathrm{E}-09$ & $1.33 \mathrm{E}-09$ \\
\hline
\end{tabular}

$\mathrm{CR}$ for As equals the sum of $\mathrm{CR}_{\mathrm{ing}}, \mathrm{CR}_{\text {inh }}$, and $\mathrm{CR}_{\text {derm }}$

dust ingestion had no adverse health threat. Although the $\mathrm{HQ}_{\text {ing }}$ rank orders of elements for three areas and two seasons were different, the high risks due to $\mathrm{HQ}_{\text {ing }}$ were found for $\mathrm{Cr}, \mathrm{As}, \mathrm{Pb}, \mathrm{Sb}$, and $\mathrm{Tl}$. The $\mathrm{HQ}_{\text {ing }}$ value of $\mathrm{Cr}$ at center area in winter $(8.59 \mathrm{E}-01)$ and $\mathrm{As}$ at extension area in summer $(8.56 \mathrm{E}-01)$ were almost equal to 1 in the case of children. A study conducted in Hefei also reported that $\mathrm{Cr}$ in dusts had high $\mathrm{HQ}_{\text {ing }}$ value [22]. Although Sr had high Ef values, its health risks in case of oral ingestion were minor regardless of areas or seasons. The $\mathrm{HQ}_{\mathrm{inh}}$ was the non-carcinogenic risk caused by pollutant exposure via direct inhalation. The result showed that the health risk was negligible due to the value of all calculated $\mathrm{HQ}_{\text {inh }}$ below unity. The high risk due to direct inhalation was associated with $\mathrm{Cr}$ and $\mathrm{Ba}$, and the lowest was for $\mathrm{Zn}$. The $\mathrm{HQ}_{\text {derm }}$ is the non-carcinogenic risk due to pollutant exposure throughout dermal contact. The same with $\mathrm{HQ}_{\text {ing }}$ and $\mathrm{HQ}_{\text {inh }}$, the health risk due to dermal contact was minor as in all the case the value of $\mathrm{HQ}_{\text {derm }}$ was less than 1. The high risks due to $\mathrm{HQ}_{\text {derm }}$ were found for $\mathrm{Cr}$, As, $\mathrm{Sb}, \mathrm{V}$, regardless of areas or seasons. A similar result was also found in Hefei [22]. It was almost common sense that non-carcinogenic risk $\left(\mathrm{HQ}_{\mathrm{ing}}, \mathrm{HQ}_{\text {inh }}, \mathrm{HQ}_{\text {derm }}\right)$ to heavy element exposure in street dusts for children was higher than for adults in the case of direct ingestion $[11,22]$. The result in our study also made no exception. The children were more vulnerable to dust exposure due to their height and playing habits [14]. Another noticeable truth was that the order of non-carcinogenic risk basically follows $\mathrm{HQ}_{\text {ing }}>\mathrm{HQ}_{\text {derm }}>\mathrm{HQ}_{\text {inh }}$, which also was suitable for our study [14, 18, 57].

The HI values equal the sum of $\mathrm{HQ}_{\text {ing }}, \mathrm{HQ}_{\text {inh }}$, and $\mathrm{HQ}_{\text {derm }}$ and reflects the total non-carcinogenic risk for any element. As a whole, the HI values for the elements were all less than the safety level of unity, which suggested a non-carcinogenic risk from heavy elements for children and adults (Fig. 5). The HI values of V,
$\mathrm{Cr}, \mathrm{As}, \mathrm{Sb}, \mathrm{Ba}, \mathrm{Tl}$, and $\mathrm{Pb}$ were obviously higher than those of other elements. Specifically, the HI values of $\mathrm{V}, \mathrm{As}$, and $\mathrm{Pb}$ for the inhabitants (children and adults) at extension area were higher than those in the other areas and the highest $\mathrm{HI}$ value of $\mathrm{Cr}$ was found at the center area. And $\mathrm{HI}$ values of $\mathrm{Sb}, \mathrm{Ba}$, and $\mathrm{Tl}$ in three areas showed little difference. Moreover, the HI value of $\mathrm{Cr}$ for inhabitants at the center area in winter was higher than that in summer, while the HI value of As for inhabitants at the extension area presented the opposite result. Although $\mathrm{HI}$ value for $\mathrm{Sb}$ was at a safe level, it had high concentration and Ef. It was believed that the exposure of heavy elements in high concentrations could cause severe neurological and development disorders, even if its HI value was at a safe level [58-59]. Therefore, the enrichment of $\mathrm{Sb}$ in street dusts in Nanchang needed to be paid more attention.

The CR for Cr, Co, Ni, As, and Cd at different areas in two seasons, which were calculated by mainly using inhalation mode of exposure, are shown in Table 2. The result shows that $\mathrm{CRs}$ of $\mathrm{Co}, \mathrm{Ni}$, and $\mathrm{Cd}$ were all less than $1 \times 10^{-6}$, implying that there was no carcinogenic risk of these metals due to urban street dust exposure. Inversely, CRs of $\mathrm{Cr}$ (mainly for children) and As contained in street dusts from three areas were higher than $1 \times 10^{-6}$, which indicated that there was potential carcinogenic risk from $\mathrm{Cr}$ and $\mathrm{As}$ in urban street dusts in Nanchang. The potential carcinogenic risk from $\mathrm{Cr}$ in street dust was found in Chengdu $\left(4.88 \times 10^{-6}\right)$ and Beijing $\left(1.28 \times 10^{-6}\right)[21,41]$. Arsenic was also found to have potential carcinogenic risk in previous studies [57, 60]. It was also found that $\mathrm{Cr}$ in dusts had the highest potential carcinogenic risk in the center area, while the highest potential carcinogenic risk of As happened in the extension area. The inhabitants possibly suffered more potential carcinogenic risks from $\mathrm{As}$ and $\mathrm{Cr}$ in winter than in summer. 
In fact, higher levels of $\mathrm{HI}$ and $\mathrm{CR}$ were observed in street dusts from center and extension areas, suggesting possibly more health risks to the inhabitants in these two areas than the fringe area, in case of heavy elements. The level of As in street dusts essentially corresponded to the natural soil background for Nanchang, and its low Ef was also found. Nevertheless, arsenic appeared to be the largest single contributor to the overall risk (HI and CR). A similar result was also reported in a previous study [60]. The immediate application of the assumed constants in the USEPA models possibly resulted in the uncertainty of health risk in Nanchang [21]. Moreover, the health risk decreased drastically by considering bioavailable fraction of metals and there was probably an overestimate of health risk in this study [12]. Furthermore, some other potential exposure to indoor dust, urban aerosol, and contaminated soil would elevate the overall risk [60]. All of these considerations indicated that the results for $\mathrm{HI}$ and $\mathrm{CR}$ in our and similar studies should be interpreted with caution. However, the relative risks among heavy elements were identified in this study. It still provided valuable information on human exposure to heavy elements through street dust that needed more attention.

\section{Conclusions}

The objectives of this study were to determine the concentrations, enrichment, and possible sources and health risks of 23 elements $(\mathrm{Ti}, \mathrm{Li}, \mathrm{Sc}, \mathrm{V}, \mathrm{Cr}, \mathrm{Co}, \mathrm{Ni}$, $\mathrm{Cu}, \mathrm{Zn}, \mathrm{Ga}, \mathrm{As}, \mathrm{Rb}, \mathrm{Sr}, \mathrm{Cd}, \mathrm{Sn}, \mathrm{Sb}, \mathrm{Te}, \mathrm{Cs}, \mathrm{Ba}, \mathrm{W}, \mathrm{Tl}$, $\mathrm{Pb}$, and $\mathrm{Bi}$ ) in street dusts along the urban expansion in two seasons (summer and winter) of Nanchang. The mean concentrations of $\mathrm{Cu}, \mathrm{Zn}, \mathrm{Cd}, \mathrm{Pb}, \mathrm{Sr}, \mathrm{Te}, \mathrm{Ba}, \mathrm{Sn}$, $\mathrm{Sb}$, and $\mathrm{Bi}$ were notably higher than their corresponding background values. The results of the MANOVA test indicated that the levels of heavy elements in street dusts varied with spatial variabilities rather than seasonality. However, seasonality had a significant effect on the comprehensive risk $\left(\mathrm{mC}_{\mathrm{d}}\right)$ of heavy elements in street dusts, and the precipitation possibly made the largest contribution. Obtained concentrations in dusts corresponded to those reported for other cities except V. Most Ef values for $\mathrm{Cu}, \mathrm{Zn}, \mathrm{Sr}, \mathrm{Te}, \mathrm{Ba}, \mathrm{Cd}, \mathrm{Sn}, \mathrm{Sb}$, $\mathrm{Pb}$, and $\mathrm{Bi}$ exceeded 2, which indicated that there was moderate enrichment in the case of these elements. The number of heavy elements influenced by anthropogenic activities decreased along urban expansion, which was consistent with the distributions of population densities and traffic flows, and could be identified as an indicator of urban expansion. The $\mathrm{mC}_{\mathrm{d}}$ values among three areas in winter had no significant difference, while it decreased significantly along the urban expansion in summer. The higher level of $\mathrm{mC}_{\mathrm{d}}$ in the center area was observed in winter more than in summer. The enrichment of $\mathrm{Cd}$, $\mathrm{Sr}$, and $\mathrm{Sb}$ accounted for $36.38-46.96 \%$ of $\mathrm{mC}_{\mathrm{d}}$. The close relationship with $\mathrm{Cd}$ and $\mathrm{Pb}$ indicated that most elements in street dusts were influenced by the traffic inputs and also had diverse sources. The HI values for all the elements below the safe level suggested noncarcinogenic risk to the inhabitants, including children and adults. There was higher $\mathrm{HI}$ level of $\mathrm{Cr}$ at the center area in winter, while higher HI level of As at extension was observed in summer. The enrichment of $\mathrm{Sb}$ in street dusts in Nanchang needed to be paid more attention due to its high concentration, $\mathrm{HI}$ and Ef values. The exposure for As and $\mathrm{Cr}$ in dusts possibly caused significant carcinogenic risk to the inhabitants.

\section{Acknowledgements}

This work was supported by the Natural Science Foundation of Jiangxi Province (20171BAB213023), the Science and Technology Research Project of Jiangxi Provincial Education Department (GJJ160276), the National Natural Science Foundation of China (41401587, 41561097), the Opening Fund of Key Laboratory of Poyang Lake Wetland and Watershed Research (Jiangxi Normal University), Ministry of Education (PK2019003), and the Young Talents Cultivation Funding Project of Jiangxi Normal University.

\section{Conflict of Interest}

The authors declare no conflict of interest.

\section{Reference}

1. UNITED NATIONS. The World's Cities in 2016, 2016.

2. LARKIN A., VAN DONKELAAR A., GEDDES J.A., MARTIN R.V., HYSTAD P. Relationships between changes in urban characteristics and air quality in East Asia from 2000 to 2010. Environmental Science \& Technology, 50 (17), 9142, 2016.

3. SOLTANI N., KESHAVARZI B., MOORE F., TAVAKOL T., LAHIJANZADEH A.R., JAAFARZADEH N., KERMANI M. Ecological and human health hazards of heavy metals and polycyclic aromatic hydrocarbons (PAHs) in street dust of Isfahan metropolis, Iran. Science of the Total Environment, 505, 712, 2015.

4. MEN C., LIU R., WANG Q., GUO L., SHEN Z. The impact of seasonal varied human activity on characteristics and sources of heavy metals in metropolitan road dusts. Science of the Total Environment, 637, 844, 2018.

5. NAKATA H., NAKAYAMA S.M., IKENAKA Y., MIZUKAWA H., ISHII C., YOHANNES Y.B., KONNAI S., DARWISH W.S., ISHIZUKA M. Metal extent in blood of livestock from Dandora dumping site, Kenya: Source identification of $\mathrm{Pb}$ exposure by stable isotope analysis. Environmental Pollution, 205, 8, 2015.

6. NOLI F., TSAMOS P. Concentration of heavy metals and trace elements in soils, waters and vegetables and assessment of health risk in the vicinity of a lignite-fired power plant. Science of the Total Environment, 563, 377, 2016.

7. GHOSH S., RABHA R., CHOWDHURY M., PADHY P.K. Source and chemical species characterization of $\mathrm{PM}_{10}$ 
and human health risk assessment of semi-urban, urban and industrial areas of West Bengal, India. Chemosphere, 207, 626, 2018.

8. SHEN Z., SUN J., CAO J., ZHANG L., ZHANG Q., LEI Y., GAO J., HUANG R.J., LIU S., HUANG Y., ZHU C., XU H.M., ZHENG C.L., LIU P., XUE Z. Chemical profiles of urban fugitive dust $\mathrm{PM}_{25}$ samples in Northern Chinese cities. Science of the Total Environment, 569, 619, 2016.

9. BI C., WANG X., JIA J., CHEN Z. Spatial variation and sources of polycyclic aromatic hydrocarbons influenced by intensive land use in an urbanized river network of East China. Science of the Total Environment, 627, 671, 2018.

10. CHEN X., LU X. Contamination characteristics and source apportionment of heavy metals in topsoil from an area in Xi'an city, China. Ecotoxicology and Environmental Safety, 151, 153, 2018.

11. BOURLIVA A., KANTIRANIS N., PAPADOPOULOU L., AIDONA E., CHRISTOPHORIDIS C., KOLLIAS P., EVGENAKIS M., FYTIANOS K. Seasonal and spatial variations of magnetic susceptibility and potentially toxic elements (PTEs) in road dusts of Thessaloniki city, Greece: A one-year monitoring period. Science of the Total Environment, 639, 417, 2018.

12. URRUTIA-GOYES R., HERNANDEZ N., CARRILLOGAMBOA O., NIGAM K.D.P., ORNELAS-SOTO N. Street dust from a heavily-populated and industrialized city: Evaluation of spatial distribution, origins, pollution, ecological risks and human health repercussions. Ecotoxicology and Environmental Safety, 159, 198, 2018.

13. MANOLI E., VOUTSA D., SAMARA C. Chemical characterization and source identification/apportionment of fine and coarse air particles in Thessaloniki, Greece. Atmospheric Environment, 36, 949, 2002.

14. MOHMAND J., EQANI S.A.M.A.S., FASOLA M., ALAMDAR A., MUSTAFA I., ALI N., LIU L., PENG S., SHEN H. Human exposure to toxic metals via contaminated dust: Bio-accumulation trends and their potential risk estimation. Chemosphere, 132, 142, 2015.

15. HUANG J., LI F., ZENG G., LIU W., HUANG X., XIAO Z., WU H., GU Y., LI X., HE X.X., HE Y. Integrating hierarchical bioavailability and population distribution into potential eco-risk assessment of heavy metals in road dust: A case study in Xiandao District, Changsha city, China. Science of the Total Environment, 541, 969, 2016.

16. TRUJILLO-GONZÁLEZ J.M., TORRES-MORA M.A., KEESSTRA S., BREVIK EC., JIMÉNEZ-BALLESTA R. Heavy metal accumulation related to population density in road dust samples taken from urban sites under different land uses. Science of the Total Environment, 553, 636, 2016.

17. ABBASI S., KESHAVARZI B., MOORE F., DELSHAB H., SOLTANI N., SOROOSHIAN A. Investigation of microrubbers, microplastics and heavy metals in street dust: a study in Bushehr city, Iran. Environmental Earth Sciences, 76 (23), 798, 2017.

18. GOPE M., MASTO R.E., GEORGE J., BALACHANDRAN S. Tracing source, distribution and health risk of potentially harmful elements (PHEs) in street dust of Durgapur, India. Ecotoxicology and Environmental Safety, 154, 280, 2018.

19. TAN Z., LU S., ZHAO H., KAI X., JIAXIAN P., WIN M.S., YU S., YONEMOCHI S., WANG Q. Magnetic, geochemical characterization and health risk assessment of road dust in Xuanwei and Fuyuan, China. Environmental Geochemistry and Health, 40, 1541, 2018.

20. ARYAL R., BEECHAM S., SARKAR B., CHONG M.N., KINSELA A., KANDASAMY J., VIGNESWARAN S.
Readily wash-off road dust and associated heavy metals on motorways. Water, Air, \& Soil Pollution, 228 (1), 1. 2017.

21. LI H.H., CHEN L.J., YU L., GUO Z.B., SHAN C.Q., LIN J.Q., GU Y.G., YANG Z.B., YANG Y.X., SHAO J.R., ZHU X.M., CHENG Z. Pollution characteristics and risk assessment of human exposure to oral bioaccessibility of heavy metals via urban street dusts from different functional areas in Chengdu, China. Science of the Total Environment, 586, 1076, 2017.

22. ALI M.U., LIU G., YOUSAF B., ABBAS Q., ULLAH H., MUNIR M.A.M., FU B. Pollution characteristics and human health risks of potentially (eco) toxic elements (PTEs) in road dust from metropolitan area of Hefei, China. Chemosphere, 181, 111, 2017.

23. ZHAO N., LU X., CHAO S. Risk assessment of potentially toxic elements in smaller than $100-\mu \mathrm{m}$ street dust particles from a valley-city in northwestern China. Environmental Geochemistry and Health, 38 (2), 483, 2016.

24. JIANG Y., SHI L., GUANG A.L., MU Z., ZHAN H., WU Y. Contamination levels and human health risk assessment of toxic heavy metals in street dust in an industrial city in Northwest China. Environmental Geochemistry and Health, 40 (5), 2007, 2018

25. XIONG S., LU B., CHENG Z., WANG H.F., HU Y. Study and forecasting change characteristics of main climatic factors in Nanchang city. Water Resources and Power, 35 (03), 15-19, 39. 2017. [In Chinese].

26. ZHANG H., WANG Z., ZHANG Y., DING M., LI L. Identification of traffic-related metals and the effects of different environments on their enrichment in roadside soils along the Qinghai-Tibet highway. Science of the Total Environment, 521,160, 2015.

27. ZHANG H., WANG Z., ZHANG Y., HU Z. The effects of the Qinghai-Tibet railway on heavy metals enrichment in soils. Science of the Total Environment, 439, 240, 2012.

28. ZHANG H., JIANG Y., DING M., XIE Z. Level, source identification, and risk analysis of heavy metal in surface sediments from river-lake ecosystems in the Poyang Lake, China. Environ. Environmental Science and Pollution Research, 24 (27), 21902, 2017.

29. LIN X.H., ZHAO Y., FAN X.J., HU G.R., YU R.L. Enrichment Characteristics and Source Analysis of Metal Elements in $\mathrm{PM}_{2.5}$ in Autumn in Nanchang City. Environmental Science, 37 (1), 35, 2016. [In Chinese].

30. HE J., XU G., ZHU H., PENG G. The Backgrounds of Soil Environment in Jiangxi Province. Environmental Science Press, Beijing. 23, 2006. [In Chinese].

31. SUTHERLAND R.A. Bed sediment-associated trace metals in an urban stream, Oahu, Hawaii. Environmental Geology, 39, 611, 2000.

32. HAKANSON L. An ecological risk index for aquatic pollution control. A sedimentological approach. Water Research, 14, 975, 1980.

33. ABRAHIM G.M.S. Holocene sediments of Tamaki Estuary: Characterization and impact of recent human activity on an urban estuary in Auckland, New Zealand. Ph.D. thesis, University of Auckland, Auckland, New Zealand. 361, 2005.

34. USEPA. Superfund Public Health Evaluation Manual. EPA/540/1e86. 1986

35. ZHANG H., JIANG Y., YANG T., WANG M., SHI G., DING M. Heavy metal concentrations and risk assessment of sediments and surface water of the Gan River, China. Polish Journal of Environmental Studies, 25, 1529, 2016. 
36. LI X., LI Z., LIN C.J., BI X., LIU J., FENG X., ZHANG H., CHEN J., WU T. Health risks of heavy metal exposure through vegetable consumption near a large-scale $\mathrm{Pb} / \mathrm{Zn}$ smelter in central China. Ecotoxicology and Environmental Safety, 161, 99, 2018.

37. USEPA. Risk Assessment Guidance for Superfund, vol. I: Human Health EvaluationManual. EPA/540/1-89/002. Office of Soild Waste and Emergency Response. US Environmental Protection Agency. Washington, D.C, 1989.

38. USEPA. Estimation of relative bioavailability of lead in soil and soil-like materials using in vivo and in vitro methods. Washington, DC: Office of Solid Waste and Emergency Response, U.S. Environmental Protection Agency, 2007.

39. USEPA. Child-specific Exposure Factors Handbook. EPA-600-P-00-002B. National Center for Environmental Assessment, 2002.

40. LI H., QIAN X., HU W., WANG Y., GAO H. Chemical speciation and human health risk of trace metals in urban street dusts from a metropolitan city, Nanjing, SE China. Science of the Total Environment, 456, 212, 2013.

41. WEI X., GAO B., WANG P., ZHOU H., LU J. Pollution characteristics and health risk assessment of heavy metals in street dusts from different functional areas in Beijing, China. Ecotoxicology and Environmental Safety, 112, 186, 2015.

42. BHANGARE R.C., AJMAL P.Y., SAHU S.K., PANDIT G.G., PURANIK V.D. Distribution of trace elements in coal and combustion residues from five thermal power plants in India. International Journal of Coal Geology, 86, 349, 2011.

43. NOVO L.A.B., ONISHI V.C., BERNARDINO C.A.R., DA SILVA E.F. Metal bioaccumulation by plants in roadside soils: perspectives for bioindication and phytoremediation. In: Anjum, N., Gill, S., Tuteja, N. (Eds.), Enhancing Cleanup of Environmental Pollutants. Springer, Cham. 215, 2017.

44. BOURLIVA A., CHRISTOPHORIDIS C., PAPADOPOULOU L., GIOURI K., PAPADOPOULOS A., MITSIKA E., FYTIANOS K. Characterization, heavy metal content and health risk assessment of urban road dusts from the historic center of the city of Thessaloniki, Greece. Environmental Geochemistry and Health, 39 (3), 611, 2017.

45. SAEEDI M., LI L.Y., SALMANZADEH, M. Heavy metals and polycyclic aromatic hydrocarbons: pollution and ecological risk assessment in street dust of Tehran. Journal of Hazardous Materials, 227, 9, 2012.

46. ZHANG H., WAN Z., DING M., WANG P., XU X., JIANG Y.. Inherent bacterial community response to multiple heavy metals in sediment from river-lake systems in the Poyang Lake, China. Ecotoxicology and Environmental Safety, 165, 314, 2018.

47. KHARE P., BARUAH B.P. Elemental characterization and source identification of $\mathrm{PM}_{2.5}$ using multivariate analysis at the suburban site of North-East India. Atmospheric Research, 98 (1), 148, 2010.
48. FARSANI M.H., SHIRMARDI M., ALAVI N., MALEKI H., SOROOSHIAN A., BABAEI A., ASGHARNIA H., MARZOUNI M.B., GOUDARZI G. Evaluation of the relationship between PM 10 concentrations and heavy metals during normal and dusty days in Ahvaz, Iran. Aeolian Research, 33, 12, 2018.

49. LIU Y.Y., WANG Y.J. Effect of climate conditions in arid area on accumulation of $\mathrm{Pd}, \mathrm{Rh}$ in dust and soil from road environment. China Environmental Science, 31 (9), 1528, 2011. [In Chinese].

50. LI X.Y. Influence of season change on the level of heavy metals in outdoor settled dusts in different functional areas of Guiyang city. Environmental Science, 34 (6), 2407, 2013.

51. HE Z.M., DENG S.R., WU Q., LI L. Variations of temperature and precipitation from 1963 to 2012 in Nanchang city. Journal of Meteorology and Environment, 34 (2), 35, 2018.

52. DUAN J., TAN J. Atmospheric heavy metals and arsenic in China: situation, sources and control policies. Atmospheric Environment, 74, 93, 2013.

53. WEI B., JIANG F., LI X., MU S. Heavy metal induced ecological risk in the city of Urumqi, NW China. Environmental Monitoring and Assessment, 160 (1-4), 33, 2010.

54. ABDULLAH M., FASOLA M., MUHAMMAD A., MALIK S.A., BOSTAN N., BOKHARI H., KRMRAN M.A., SHAFQAT M.N., ALAMDAR A., KHAN M., ALI N., EQANI S.A.M.A.S. Avian feathers as a non-destructive bio-monitoring tool of trace metals signatures: a case study from severely contaminated areas. Chemosphere, 119, 553, 2017.

55. YILDIRIM G., TOKALIOĞLU Ş. Heavy metal speciation in various grain sizes of industrially contaminated street dust using multivariate statistical analysis. Ecotoxicology and Environmental Safety, 124, 369, 2016.

56. WANG C., WU S., ZHOU S., WANG H., LI B., CHEN H., YU Y., SHI Y. Polycyclic aromatic hydrocarbons in soils from urban to rural areas in Nanjing: concentration, source, spatial distribution, and potential human health risk. Science of the Total Environment, 527, 375, 2015.

57. FERREIRA-BAPTISTA L., DE MIGUEL E. Geochemistry and risk assessment of street dust in Luanda, Angola: a tropical urban environment. Atmospheric Environment, 39 (25), 4501, 2005.

58. HE K., WANG S., ZHANG J. Blood lead levels of children and its trend in China. Science of the Total Environment, 407, 3986, 2009.

59. CHENG H.F., HU Y.A. Lead (Pb) isotopic fingerprinting and its applications in lead pollution studies in China: a review. Environmental Pollution, 158 (5), 1134, 2010.

60. DE MIGUEL E., IRIBARREN I., CHACON E., ORDONEZ A., CHARLESWORTH S. Risk-based evaluation of the exposure of children to trace elements in playgrounds in Madrid (Spain). Chemosphere, 66 (3), 505, 2007. 


\title{
Supporting Information
}

\section{The Pollution Characteristics of Heavy Element in Street Dusts Along the Urban Expansion in Metropolitan Area of Nanchang City, China}

\author{
Xiaoling Xü ${ }^{1}$, Hua Zhang ${ }^{1,2 *}$, Xiaoying Xiong ${ }^{1}$, Huaming Zhang ${ }^{1}$, \\ Huan Zeng ${ }^{1}$, Wenjing Yang ${ }^{1,2}$
}

${ }^{1}$ Key Laboratory of Education Ministry for Poyang Lake Wetland and Watershed Research, Geography and Environmental College, Jiangxi Normal University, Nanchang, P.R. China

${ }^{2}$ Jiangxi Provincial Key Laboratory of Poyang Lake Comprehensive Management and Resource Development, Jiangxi Normal University, Nanchang, China

Table S1. Meteorological parameters recorded during the sampling period (national meteorological information center of China).

\begin{tabular}{|c|c|c|}
\hline Season & Summer & Winter \\
\hline \multicolumn{3}{|c|}{ Temperature, ${ }^{\circ} \mathrm{C}$} \\
\hline Mean & 27.4 & 6.3 \\
\hline Minimum & 24.7 & 4.5 \\
\hline Maximum & 31.2 & 8.8 \\
\hline \multicolumn{3}{|c|}{ Relative humidity (\%) } \\
\hline Mean & 78 & 77 \\
\hline Minimum & 42 & 20 \\
\hline \multicolumn{3}{|c|}{ Rainfall (mm/ month) } \\
\hline Amount & 237.8 & 131.1 \\
\hline Mean & 1.9 & 1.8 \\
\hline Maximum & 7.3 & 5.7 \\
\hline Wind direction & Southeast (SE) & Northeast (NE) \\
\hline
\end{tabular}

Table S2. The parameters related to anthropogenic activity in different areas.

\begin{tabular}{|c|c|c|}
\hline Area & $\begin{array}{c}\text { Population density } \\
\left.\text { (thousand people } / \mathrm{km}^{2}\right)^{\mathrm{a}}\end{array}$ & $\begin{array}{c}\text { Traffic flow } \\
(\text { Vehicle } / \mathrm{h} \text { ) }\end{array}$ \\
\hline Center & 12.2 & 6360 \\
\hline Extension & 3.19 & 4427 \\
\hline Fringe & 2.16 & 2162 \\
\hline
\end{tabular}

a. the population density is the ration of the permanent people to the whole area

b. the traffic flow was monitored in the typical section in the same road straightly from the center to the fringe area, and the time synchronously happened from 14: 00 to $15: 00$ in same day in winter.

Table S3. Ef and $\mathrm{mC}_{\mathrm{d}}$ categories for heavy elements.

\begin{tabular}{|c|c|}
\hline Value & Category \\
\hline $\mathrm{Ef}<2$ & Depletion to minimal pollution \\
\hline $2<\mathrm{Ef} \leq 5$ & Moderate pollution \\
\hline $5<\mathrm{Ef} \leq 20$ & Significant pollution \\
\hline $20<\mathrm{Ef} \leq 40$ & Strong pollution \\
\hline $40<\mathrm{Ef}$ & Extreme pollution \\
\hline
\end{tabular}


Table S4. The parameters used in the USEPA models.

\begin{tabular}{|c|c|c|c|c|}
\hline \multirow{2}{*}{ Parameters } & \multirow{2}{*}{ Description and units } & \multicolumn{2}{|c|}{ Values } & \multirow{2}{*}{ References } \\
\hline & & Adult & Children & \\
\hline $\mathrm{ABF}$ & Absorption factor (Dermal) & \multicolumn{2}{|c|}{0.001} & [1-3] USEPA (2001a, 2001b), Wei et al., 2015 \\
\hline $\mathrm{AF}$ & Skin adherence factor $\left(\mathrm{mg} \mathrm{cm}^{-2}\right)$ & 0.07 & 0.2 & [4-5] USEPA $(1996,2001)$ \\
\hline AT & Average time (days) & \multicolumn{2}{|c|}{$365 \times \mathrm{ED}$} & [6] USEPA, 1989 \\
\hline BW & Body weight (kg) & 55.9 & 15 & [7-8] ESAG (2009), Zheng et al., 2010 \\
\hline $\mathrm{CF}$ & Conversion factor $\left(\mathrm{kg} \mathrm{mg}^{-1}\right)$ & \multicolumn{2}{|c|}{$1.00 \mathrm{E}-06$} & [9] Li et al. (2001) \\
\hline $\mathrm{ED}$ & Exposure duration (years) & 24 & 6 & [1-2] USEPA (2001a, 2001b); [10]USEPA, 2002 \\
\hline $\mathrm{EF}$ & Exposure frequency (days year-1 $\left.{ }^{-1}\right)$ & \multicolumn{2}{|c|}{350} & [8] Zheng et al., 2010 \\
\hline IngR & Ingestion rate of dust (mg day $\left.{ }^{-1}\right)$ & 100 & 200 & [7, 11] ESAG (2009); Van den Berg 1995 \\
\hline $\operatorname{InhR}$ & Inhalation rate of dust $\left(\mathrm{m}^{3} \mathrm{~kg}^{-1}\right)$ & 12.8 & 7.63 & [7, 9] Li et al. (2001); USEPA, 2002 \\
\hline $\mathrm{PEF}$ & Particular emission rate $\left(\mathrm{m}^{3} \mathrm{~kg}^{-1}\right)$ & \multicolumn{2}{|c|}{$1.36 \mathrm{E}+09$} & [1-2] USEPA (2001a, 2001b) \\
\hline SA & Surface area of skin exposed to dust $\left(\mathrm{cm}^{2}\right)$ & 4350 & 1600 & [7-8] ESAG (2009); Zheng et al., 2010 \\
\hline
\end{tabular}

Table S5. Multivariate Analysis of Variance (MANOVA) results of heavy element in street dusts of Nanchang city.

\begin{tabular}{|c|c|c|c|c|c|c|}
\hline \multirow{2}{*}{ Metals } & \multicolumn{2}{|c|}{ Season } & \multicolumn{2}{c|}{ Area } & \multicolumn{2}{c|}{ Season $\times$ area } \\
\cline { 2 - 7 } & $F$ & sig & $F$ & sig & $F$ & sig \\
\hline $\mathrm{Ti}$ & 5.822 & 0.017 & $\mathbf{5 . 7 9 5}$ & $\mathbf{0 . 0 0 4}$ & $\mathbf{1 0 . 6 6 0}$ & $\mathbf{0 . 0 0 0}$ \\
\hline $\mathrm{Li}$ & 3.171 & 0.077 & 0.811 & 0.446 & 2.377 & 0.097 \\
\hline $\mathrm{Sc}$ & 0.046 & 0.830 & 0.053 & 0.949 & 4.263 & 0.016 \\
\hline $\mathrm{V}$ & 5.746 & 0.018 & 33.032 & 0.000 & 3.331 & $\mathbf{0 . 0 3 9}$ \\
\hline $\mathbf{C r}$ & 2.849 & 0.094 & 5.581 & 0.005 & 0.259 & 0.772 \\
\hline $\mathbf{C o}$ & 1.027 & 0.313 & 15.100 & 0.000 & 7.156 & 0.001 \\
\hline $\mathrm{Ni}$ & 0.059 & 0.809 & 9.659 & 0.000 & 1.165 & 0.315 \\
\hline $\mathbf{C u}$ & 0.121 & 0.728 & 10.205 & 0.000 & $\mathbf{4 . 1 5 6}$ & $\mathbf{0 . 0 1 8}$ \\
\hline $\mathbf{Z n}$ & 0.733 & 0.393 & 3.251 & 0.042 & 0.283 & 0.754 \\
\hline $\mathrm{Ga}$ & 0.156 & 0.693 & 7.811 & 0.001 & $\mathbf{4 . 4 3 8}$ & $\mathbf{0 . 0 1 4}$ \\
\hline $\mathbf{A s}$ & 0.058 & 0.810 & 7.413 & 0.001 & 2.627 & 0.076 \\
\hline $\mathbf{R b}$ & $\mathbf{1 5 . 8 8 5}$ & $\mathbf{0 . 0 0 0}$ & 5.124 & 0.007 & 1.677 & 0.191 \\
\hline $\mathbf{S r}$ & $\mathbf{4 . 4 8 5}$ & $\mathbf{0 . 0 3 6}$ & 0.300 & 0.741 & 0.071 & 0.932 \\
\hline $\mathbf{C d}$ & 2.681 & 0.104 & 4.116 & 0.018 & 1.733 & 0.181 \\
\hline $\mathbf{S n}$ & 0.062 & 0.804 & 16.192 & 0.000 & 0.402 & 0.670 \\
\hline $\mathrm{Sb}$ & 2.151 & 0.145 & 3.255 & 0.042 & 0.519 & 0.596 \\
\hline $\mathbf{T e}$ & 0.015 & 0.901 & 7.965 & 0.001 & 2.738 & 0.068 \\
\hline $\mathbf{C s}$ & $\mathbf{6 . 7 6 8}$ & 0.010 & 0.114 & 0.892 & 0.974 & 0.380 \\
\hline $\mathbf{B a}$ & 1.337 & 0.250 & 6.117 & 0.003 & 0.376 & 0.687 \\
\hline $\mathbf{W}$ & 0.686 & 0.409 & 2.367 & 0.098 & 1.038 & 0.357 \\
\hline $\mathbf{T l}$ & $\mathbf{1 1 . 1 7 1}$ & $\mathbf{0 . 0 0 1}$ & 5.116 & 0.007 & 0.329 & 0.720 \\
\hline $\mathbf{P b}$ & 0.749 & 0.388 & 1.616 & 0.203 & 0.585 & 0.558 \\
\hline $\mathbf{B i}$ & 0.862 & 0.355 & 3.630 & 0.029 & 1.855 & 0.161 \\
\hline & & & & & & \\
\hline & & & & \\
\hline
\end{tabular}




\begin{tabular}{|c|c|c|c|c|c|c|c|c|c|c|c|c|c|c|c|c|c|c|}
\hline 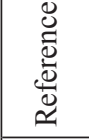 & $\stackrel{n}{E}$ & 窟 & $\Xi \Xi$ & & E & $\stackrel{\curvearrowleft}{\Xi}$ & $\stackrel{\square}{\Xi}$ & $\Xi$ & $\stackrel{\infty}{\Xi}$ & $\Xi$ & 离 & $\bar{\Xi}$ & $\overline{\mathbb{Z}}$ & $\bar{\beth}$ & $\underset{\Xi}{\stackrel{\Xi}{U}}$ & $\sqrt[n]{\beth}$ & 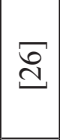 & 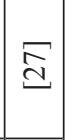 \\
\hline$\vec{n}$ & : & $\stackrel{n}{?}$ & & & & & & & & & & & & & & & & \\
\hline $\overrightarrow{2}$ & \begin{tabular}{c|c}
$m$ & \\
$\infty$ & \\
$\infty$ &
\end{tabular} & 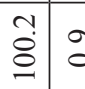 & \begin{tabular}{l|l}
0 \\
$\dot{0}$ \\
$\dot{\Xi}$
\end{tabular} & $\begin{array}{l}0 \\
\mathrm{i} \\
\end{array}$ & \begin{tabular}{|l|} 
\\
\\
\end{tabular} & \begin{tabular}{l|l}
$\stackrel{n}{*}$ \\
$\stackrel{\sim}{I}$
\end{tabular} & 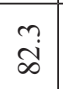 & $\stackrel{\circ}{\stackrel{2}{I}}$ & $\hat{i}$ & $\hat{i}$ & \begin{tabular}{|c|} 
\\
\end{tabular} & $\begin{array}{l}0 \\
\dot{0} \\
0\end{array}$ & @্ণ্ণি & $\stackrel{0}{\stackrel{0}{\sim}}$ & $\stackrel{\circ}{\circ}$ & 芦 & $\underset{\mid}{\stackrel{\infty}{+}}$ & $\begin{array}{l}0 \\
\dot{0} \\
\hat{\sigma}\end{array}$ \\
\hline$F$ & $\begin{array}{l}0 \\
:\end{array}$ & $\stackrel{0}{\circ}$ & & & & & & & & & & & & & & & & \\
\hline 3 & \begin{tabular}{l|l} 
\\
\\
\end{tabular} & $\stackrel{\circ}{\infty}$ & & & & & & & & & & & & & & & & \\
\hline$\tilde{\oplus}$ & \begin{tabular}{l|} 
\\
0 \\
0 \\
0 \\
0
\end{tabular} & 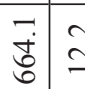 & $\stackrel{\sim}{I}$ & & & & & & & $\begin{array}{l} \\
\dot{a} \\
y\end{array}$ & & & $\begin{array}{l}0 \\
\stackrel{0}{0} \\
\text { n్ }\end{array}$ & & & & & \\
\hline 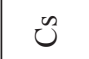 & $\begin{array}{ll}\infty & 1 \\
i & \end{array}$ & $?$ & & & & & & & & & & & & & & & & \\
\hline$\oplus$ & \begin{tabular}{l|l}
\multirow{2}{*}{} & \\
\end{tabular} & ชี & & & & & & & & & & & & & & & & \\
\hline ह & \begin{tabular}{c|c}
$m$ & \\
$\infty$ &
\end{tabular} & $\underset{a}{m}$ & . & & & & & & & & & & & & & & & \\
\hline कี & $\begin{array}{l}\hat{i} \\
\text { I }\end{array}$ & \begin{tabular}{l|l}
\multirow{2}{*}{} & I
\end{tabular} & ฯ & & & & & & & & & & & & & & & \\
\hline$\tilde{J}$ & $\dot{o}$ & $\exists$ & $\vec{a}$ & \begin{tabular}{ll|}
0 \\
0
\end{tabular} & $\because$ & & $I$ & $\stackrel{\infty}{i}$ & & & $\because$ & $\exists$ & $\stackrel{i}{i}$ & $\stackrel{m}{o}$ & $\begin{array}{l}\infty \\
0\end{array}$ & $\hat{0}$ & $\stackrel{0}{-}$ & $=$ \\
\hline is & \begin{tabular}{l|}
$\infty$ \\
$\dot{\vec{N}}$ \\
$\overrightarrow{\mathrm{N}}$
\end{tabular} & $\begin{array}{l}n \\
i \\
\tilde{n}\end{array}$ & & & & & & & & \begin{tabular}{|l|}
$\infty$ \\
$i$ \\
$i$ \\
$n$
\end{tabular} & & & हे & & & & & \\
\hline 요 & $\begin{array}{l}\dot{\Xi} \\
\stackrel{0}{0}\end{array}$ & 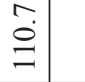 & & & & & & & & & & & & & & & & \\
\hline$<$ & $\stackrel{?}{\varrho}$ & $\stackrel{\overbrace{}}{\varrho}$ & $\stackrel{i}{i}$ & $\stackrel{+}{\dot{\tau}}$ & $\vec{F}$ & & & & & \begin{tabular}{|c|} 
\\
$\dot{m}$
\end{tabular} & \begin{tabular}{|c|}
$\dot{\vec{d}}$ \\
\end{tabular} & $\stackrel{+}{\vec{d}}$ & & 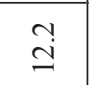 & & & & \\
\hline$\pi$ & \begin{tabular}{l|l} 
& 0 \\
$\stackrel{0}{0}$ &
\end{tabular} & \begin{tabular}{l|l}
0 & 0 \\
$\stackrel{\varrho}{\varrho}$ & $\approx$
\end{tabular} & $\begin{array}{l}6 \\
\infty \\
\infty\end{array}$ & & & & & & & & & & & & & & & \\
\hline ㄱ & \begin{tabular}{|c|c} 
\\
$\vdots$ \\
$m$
\end{tabular} & 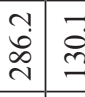 & \begin{tabular}{l|l}
$\overrightarrow{\dot{d}}$ \\
$\dot{\vec{v}}$ \\
\end{tabular} & $\begin{array}{c}0 \\
\stackrel{0}{0} \\
\dot{0} \\
i\end{array}$ & 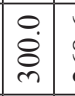 & 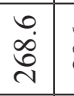 & ৯े & $\stackrel{n}{\stackrel{n}{n}}$ & 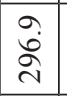 & $\begin{array}{l} \\
0 \\
0 \\
0 \\
\end{array}$ & & $\begin{array}{l}\circ \\
\dot{+} \\
\dot{m}\end{array}$ & $\begin{array}{l}\dot{0} \\
\dot{D} \\
\stackrel{D}{n}\end{array}$ & 竎 & 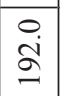 & $\underset{\infty}{\infty}$ & $\begin{array}{l}0 \\
\stackrel{\dot{b}}{n} \\
\tilde{n}\end{array}$ & $\frac{\circ}{\dot{a}}$ \\
\hline J & $\stackrel{\vec{a}}{\vec{\alpha}}$ & \begin{tabular}{l|l}
0 & 0 \\
$\stackrel{\leftrightarrow}{\circ}$ & $\bar{\sigma}$
\end{tabular} & 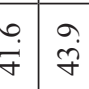 & $\begin{array}{c}0 \\
\infty \\
\infty\end{array}$ & \begin{tabular}{l|} 
\\
\end{tabular} & 官 & 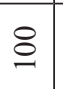 & $\stackrel{?}{\stackrel{9}{0}}$ & $\stackrel{0}{i}$ & \begin{tabular}{l|}
0 \\
$\dot{q}$ \\
$\dot{q}$
\end{tabular} & $\begin{array}{l}n \\
n \\
n\end{array}$ & 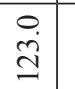 & $\stackrel{0}{\stackrel{0}{0}}$ & $\underset{\infty}{\sim}$ & $\stackrel{\sim}{=}$ & 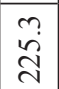 & 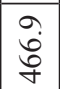 & $\begin{array}{l}0 \\
\stackrel{j}{d}\end{array}$ \\
\hline $\bar{z}$ & 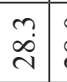 & \begin{tabular}{c|c} 
& 0 \\
$\dot{\phi}$ & 0 \\
$\sim$ & $\infty$ \\
\end{tabular} & 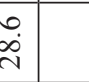 & $\begin{array}{l}\dot{m} \\
\dot{m}\end{array}$ & \begin{tabular}{|c|}
$\stackrel{\partial}{\dot{\gamma}}$ \\
\end{tabular} & 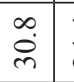 & \begin{tabular}{l}
\multirow{d}{*}{} \\
\end{tabular} & $\overrightarrow{\vec{H}}$ & & \begin{tabular}{|l|}
\multirow{2}{*}{} \\
iे
\end{tabular} & & 官 & $\stackrel{\circ}{i}$ & $\stackrel{\overbrace{}}{\dot{m}}$ & \begin{tabular}{|l|}
$\infty$ \\
$\dot{m}$ \\
\end{tabular} & & $\vec{F}$ & $\stackrel{?}{0}$ \\
\hline ن & $\stackrel{+}{\circ}$ & 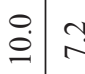 & ry & & & ठे. & & $\stackrel{\partial}{\dot{J}}$ & & $\overrightarrow{0}$ & & $\hat{0}$ & $\stackrel{\circ}{\dot{m}}$ & & & & & \\
\hline Ü & 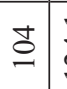 & \begin{tabular}{l|l}
$\overrightarrow{\dot{I}}$ & $m$ \\
$\stackrel{2}{2}$
\end{tabular} & 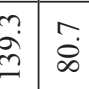 & $\begin{array}{l}0 \\
\dot{0}\end{array}$ & $\begin{array}{l}0 \\
\dot{0} \\
\infty\end{array}$ & 证 & $\begin{array}{l}\text { ? } \\
\dot{\infty}\end{array}$ & 离 & $\overrightarrow{\mathrm{d}}$ & \begin{tabular}{|c|} 
\\
$\dot{p}$ \\
$i n$ \\
$i n$
\end{tabular} & $\stackrel{a}{\overrightarrow{2}}$ & $\begin{array}{l}0 \\
\stackrel{0}{0} \\
\text { I }\end{array}$ & $\begin{array}{l}\infty \\
\infty \\
\infty \\
\infty\end{array}$ & ळे & $\stackrel{n}{m}$ & & & $\stackrel{m}{\infty}$ \\
\hline$>$ & $\stackrel{\vec{j}}{\grave{S}}$ & \begin{tabular}{l|l}
$n$ \\
$\stackrel{n}{2}$
\end{tabular} & d. & & & $\begin{array}{l}0 . \\
80\end{array}$ & & हे & & $\begin{array}{l}\overrightarrow{5} \\
\text { in }\end{array}$ & & $\begin{array}{l}0 \\
\stackrel{+}{i}\end{array}$ & $\stackrel{\circ}{i}$ & & & & & \\
\hline$\ddot{n}$ & $n$ & $\hat{\sigma}$ & & & & & & & & & & & & & & & & \\
\hline ב & $\begin{array}{l}0 \\
\dot{D} \\
\dot{m}\end{array}$ & $\stackrel{m}{\vec{n}} \stackrel{m}{2}$ & อุ & & & & & & & & & & & & & $a$ & & 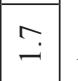 \\
\hline$F$ & $\frac{\infty}{m}$ & 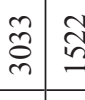 & है & & & & & & & & & & & & & & & \\
\hline Q 䒠 & $\hat{\delta}$ & \begin{tabular}{l|l}
$\hat{B}$ & $\hat{v}$
\end{tabular} & $\stackrel{\tilde{V}}{\hat{V}} \hat{\stackrel{V}{V}}$ & & & $\stackrel{n}{v}$ & $\begin{array}{l}3 \\
v\end{array}$ & $\tilde{b}$ & $\stackrel{n}{\hat{v}}$ & $\stackrel{8}{\vec{\nabla}}$ & $\tilde{\hat{\sigma}}$ & $\hat{\beta}$ & \&્ત & \&े & $\tilde{\hat{v}}$ & $\hat{\mathrm{v}}$ & $\hat{\mathrm{B}}$ & $\underset{\sim}{\stackrel{\sim}{V}}$ \\
\hline 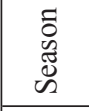 & $\infty$ & 30 & $s<$ & $\infty$ & 3 & हे & $\varangle$ & \& & 3 & in & ' & $\varangle$ & \& & ' & $n$ & $n$ & $\infty$ & n \\
\hline$\stackrel{9}{5}$ & 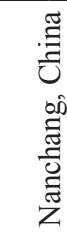 & 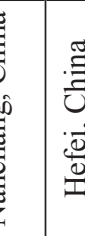 & 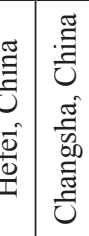 & $\begin{array}{l}\text {. } \\
0 \\
\vdots \\
0 \\
0\end{array}$ & 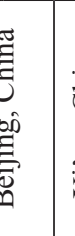 & 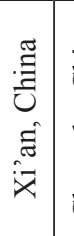 & 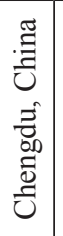 & 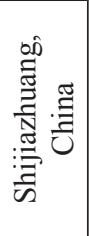 & 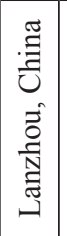 & 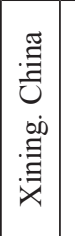 & 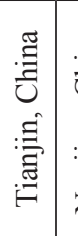 & 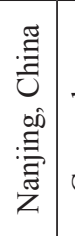 & 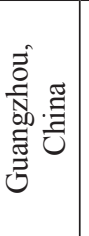 & 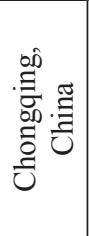 & 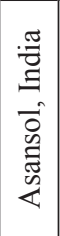 & 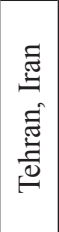 & 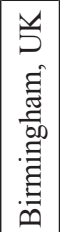 & 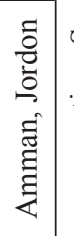 \\
\hline
\end{tabular}




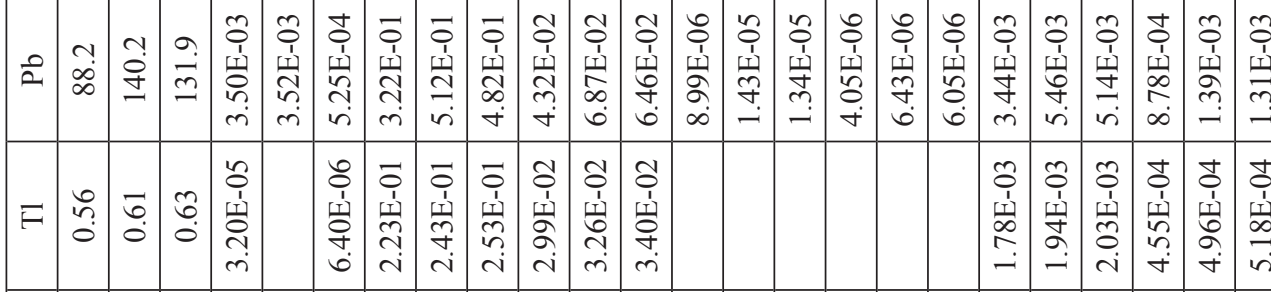

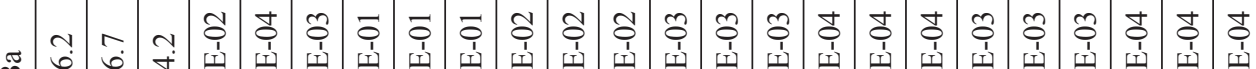
ஜ

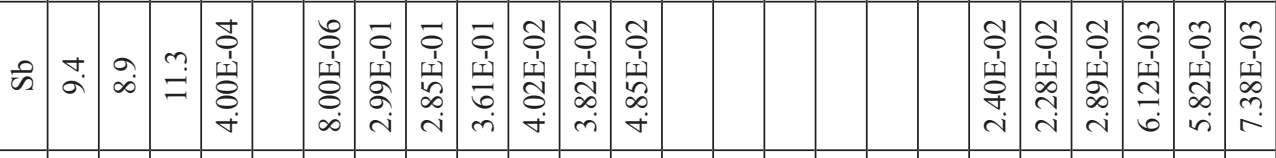

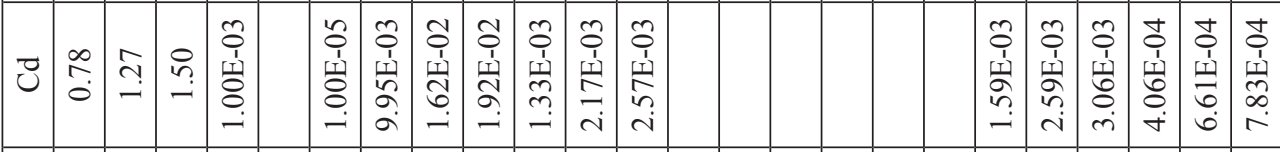

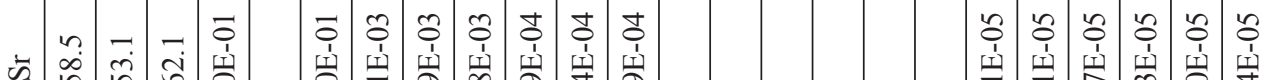

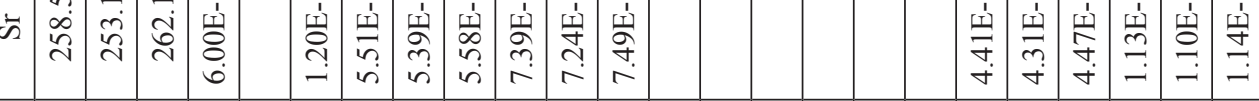

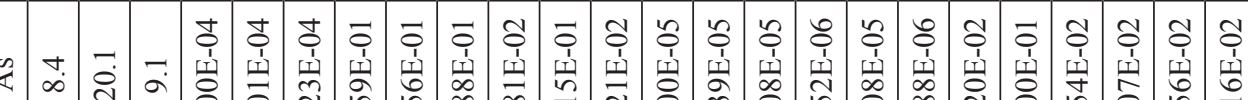

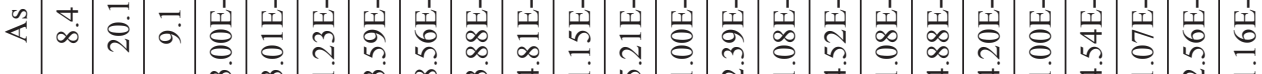

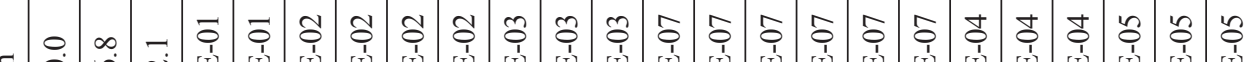

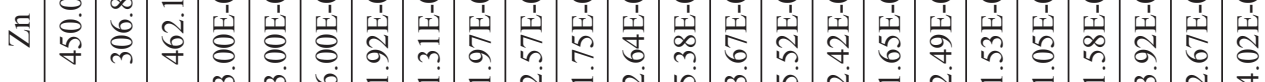

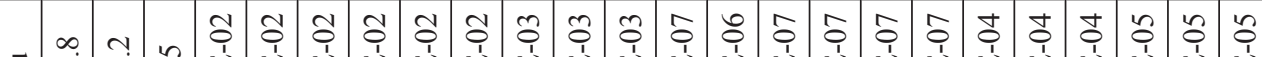

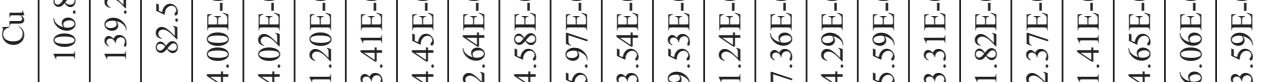

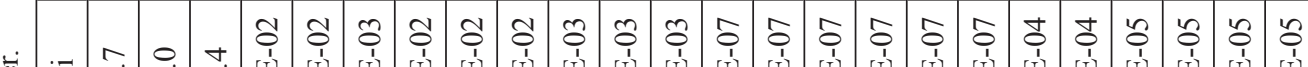

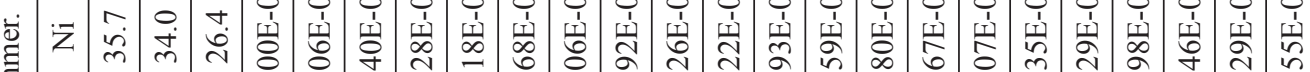

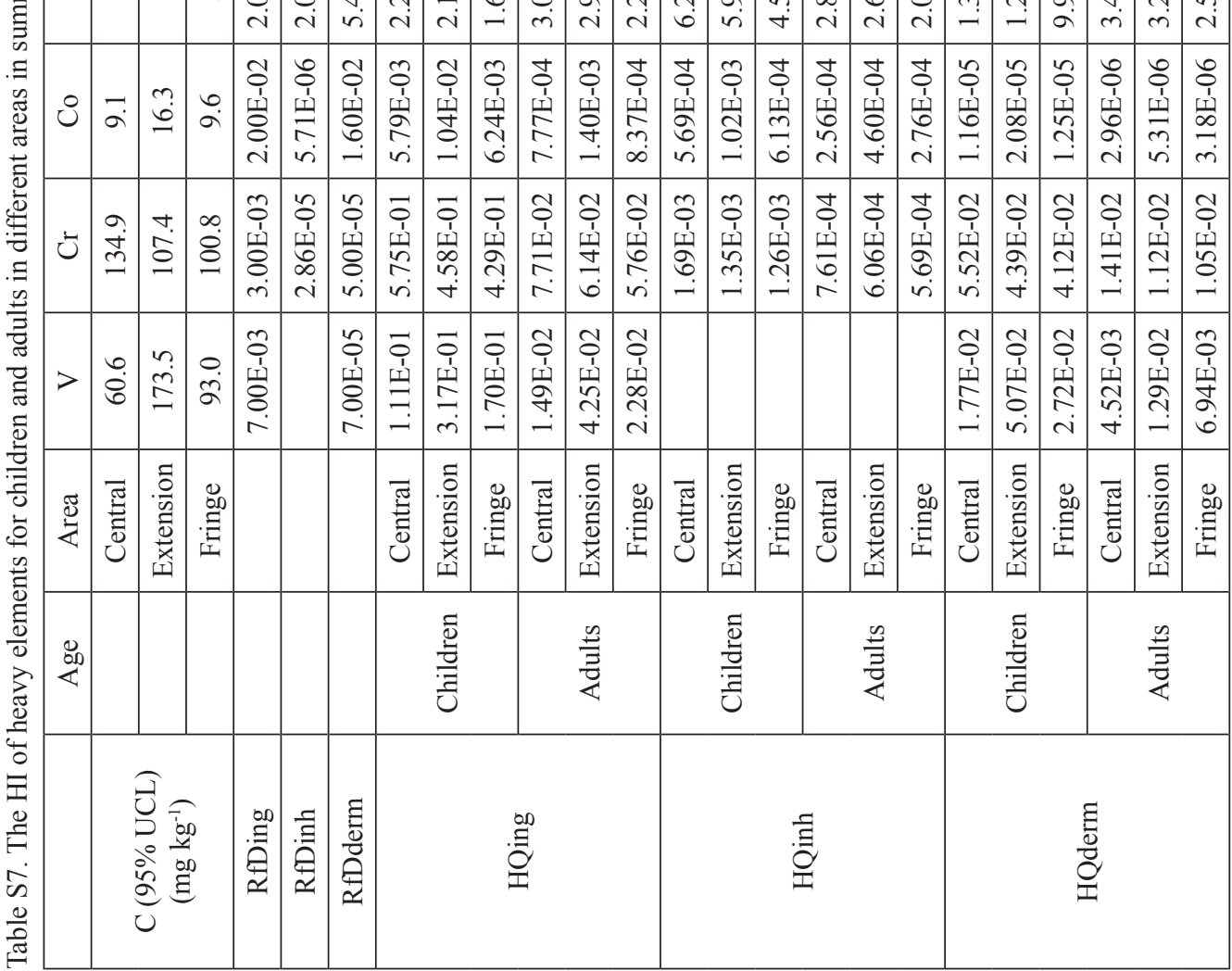




\section{Reference}

1. USEPA. Risk Assessment Guidance for Superfund: Volume III-part A, Process for Conducting Probabilistic Risk Assessment. Washington, D.C.EPA540-R- 02-002, 2001a.

2. USEPA. Child-specific Exposure Factors Handbook. EPA-600-P-00-002B. National Center for Environmental Assessment, 2001b.

3. WEI X., GAO B., WANG P., ZHOU H., LU J. Pollution characteristics and health risk assessment of heavy metals in street dusts from different functional areas in Beijing, China. Ecotoxicology and Environmental Safety, 112, 186, 2015.

4. USEPA. Soil Screening Guidance: Technical Background Document. EPA/540/R-95/128. Office of Soild Waste and Emergency Response. U.S. Environmental Protection Agency. Washington, D.C., 1996.

5. USEPA. Supplemental Guidance for Developing Soil Screening Levels for Superfund Sites. OSWER 9355.424. Office of Soild Waste and Emergency Response. U.S. Environmental Protection Agency. Washington, D.C, 2001.

6. USEPA. Risk Assessment Guidance for Super Fund, vol. I (Human Health Evaluation Manual), 1989.

7. ESAG (Environmental Site Assessment Guideline), 2009. DB11/T656-2009. [In Chinese].

8. ZHENG N., LIU J., WANG Q., LIANG Z. Health risk assessment of heavy metal exposure to street dust in the zinc smelting district, Northeast of China. Science of the Total Environment, 408, 726, 2010.

9. LI X.D., POON C.S., HUI P.S. Heavy metal contamination of urban soils and street dust in Hong Kong. Applied Geochemistry, 16, 1361, 2001.

10. USEPA. Child-specific Exposure Factors Handbook. EPA-600-P-00-002B. National Center for Environmental Assessment, 2002.

11. VAN DEN BERG R. Human Exposure to Soil Contamination: a Qualitative and Quantitative Analysis towards Proposals for Human Toxicological Intervention Values. National Institute of Public Health and Environmental Protection (RIVM), Bilthoven, the Netherlands (RIVM Report no. 725201011), 1995.

12. ALI M.U., LIU G., YOUSAF B., ABBAS Q., ULLAH H., MUNIR M.A.M., FU B. Pollution characteristics and human health risks of potentially (eco) toxic elements (PTEs) in road dust from metropolitan area of Hefei, China. Chemosphere, 181, 111, 2017.

13. HUANG J., LI F., ZENG G., LIU W., HUANG X., XIAO Z., WU H., GU Y., LI X., HE X.X., HE Y. Integrating hierarchical bioavailability and population distribution into potential eco-risk assessment of heavy metals in road dust: A case study in Xiandao District, Changsha city, China. Science of the Total Environment, 541, 969, 2016.

14. MEN, C., LIU, R., WANG, Q., GUO, L., SHEN, Z. The impact of seasonal varied human activity on characteristics and sources of heavy metals in metropolitan road dusts. Science of the Total Environment, 637, 844, 2018.

15. PAN H., LU X., LEI K. A comprehensive analysis of heavy metals in urban road dust of Xi'an, China: Contamination, source apportionment and spatial distribution. Science of the Total Environment, 609, 1361, 2017.

16. LI H.H., CHEN L.J., YU L., GUO Z.B., SHAN C.Q., LIN J.Q., GU Y.G., YANG Z.B., YANG Y.X., SHAO J.R., ZHU X.M., CHENG Z. Pollution characteristics and risk assessment of human exposure to oral bioaccessibility of heavy metals via urban street dusts from different functional areas in Chengdu, China. Science of the Total Environment, 586, 1076, 2017.

17. WAN D., HAN, Z., YANG J., YANG G., LIU X. Heavy metal pollution in settled dust associated with different urban functional areas in a heavily air-polluted city in North China. International Journal of Environmental Research and Public Health, 13 (11), 1119, 2016.

18. JIANG Y., SHI L., GUANG A.L., MU Z., ZHAN H., WU Y. Contamination levels and human health risk assessment of toxic heavy metals in street dust in an industrial city in Northwest China. Environmental Geochemistry and Health, 40, 2007, 2018.

19. ZHAO N., LU X., CHAO S. Risk assessment of potentially toxic elements in smaller than $100-\mu \mathrm{m}$ street dust particles from a valley-city in northwestern China. Environ. Environmental Geochemistry and Health, 38 (2), 483, 2016.

20. YU B., WANG Y., ZHOU Q. Human health risk assessment based on toxicity characteristic leaching procedure and simple bioaccessibility extraction test of toxic metals in urban street dust of Tianjin, China. PLoS One, 9 (3), e92459, 2014.

21. HU X., ZHANG Y., LUO J., WANG T., LIAN H., DING $Z$. Bioaccessibility and health risk of arsenic, mercury and other metals in urban street dusts from a mega-city, Nanjing, China. Environmental Pollution, 159, 1215, 2011.

22. DUZGOREN-AYDIN N.S., WONG C., AYDIN A., SONG Z., YOU M., LI X.D. Heavy metal contamination and distribution in the urban environment of Guangzhou, SE China. Environmental Geochemistry and Health, 28 (4), 375, 2006.

23. LI Y.Y., LI Z.P., XIONG H.L., CHEN Y.C., DAI Y. Risk assessment of roadside heavy metal pollution to human health in Chongqing. Journal of Southwest University. 37 (2), 18, 2015. [In Chinese]

24. GOPE M., MASTO R.E., GEORGE J., BALACHANDRAN S. Tracing source, distribution and health risk of potentially harmful elements (PHEs) in street dust of Durgapur, India. Ecotoxicology and Environmental Safety, 154, 280, 2018.

25. SAEEDI M., LI L.Y., SALMANZADEH M. Heavy metals and polycyclic aromatic hydrocarbons: pollution and ecological risk assessment in street dust of Tehran. Journal of Hazardous Materials, 227, 9, 2012.

26. CHARLESWORTH S., EVERETT M., MCCARTHY R., ORDONEZ A., DE MIGUEL E. A comparative study of heavy metal concentration and distribution in deposited street dusts in a large and a small urban area: Birmingham and Coventry, West Midlands, UK. Environment International, 29 (5), 563, 2003.

27. JIRIES A. Vehicular contamination of dust in Amman, Jordan. Environmentalist, 23 (3), 205, 2003. 
